\title{
WestVirginiaUniversity
}

THE RESEARCH REPOSITORY @ WVU

Graduate Theses, Dissertations, and Problem Reports

2010

\section{Mechanisms of Tungsten Carbide-Cobalt Nanoparticle-induced Angiogenesis}

Yingxue Zhu

West Virginia University

Follow this and additional works at: https://researchrepository.wvu.edu/etd

\section{Recommended Citation}

Zhu, Yingxue, "Mechanisms of Tungsten Carbide-Cobalt Nanoparticle-induced Angiogenesis" (2010). Graduate Theses, Dissertations, and Problem Reports. 3080.

https://researchrepository.wvu.edu/etd/3080

This Thesis is protected by copyright and/or related rights. It has been brought to you by the The Research Repository @ WVU with permission from the rights-holder(s). You are free to use this Thesis in any way that is permitted by the copyright and related rights legislation that applies to your use. For other uses you must obtain permission from the rights-holder(s) directly, unless additional rights are indicated by a Creative Commons license in the record and/ or on the work itself. This Thesis has been accepted for inclusion in WVU Graduate Theses, Dissertations, and Problem Reports collection by an authorized administrator of The Research Repository @ WVU. For more information, please contact researchrepository@mail.wvu.edu. 


\title{
Mechanisms of Tungsten Carbide-Cobalt Nanoparticle-induced Angiogenesis
}

\author{
Yingxue Zhu \\ Thesis submitted to the Davis College of Agriculture, \\ Natural Resources and Design \\ at West Virginia University \\ in partial fulfillment of the requirements \\ for the degree of \\ Master of Science \\ in \\ Genetics \& Developmental Biology \\ Bingyun Li, Ph.D., Chair \\ Sharon L.Wenger, Ph.D. \\ Bing-Hua Jiang, Ph.D. \\ Genetics \& Developmental Biology Program \\ Morgantown, West Virginia \\ 2010
}

Keywords: PI3K, WC-Co, ROS, AKT, PI3K, MEK, ERK, AP-1, angiogenesis

Copyright 2010 Yingxue Zhu 


\title{
ABSTRACT \\ Mechanisms of Tungsten Carbide-Cobalt
}

\author{
Nanoparticle- induced Angiogenesis
}

Yingxue Zhu

Hard metal or cemented carbide consists of a powder mixture of 80 to $90 \%$ of tungsten carbide (WC) and 5 to $10 \%$ of metallic cobalt (Co). Nanoparticles are engineered structures with one dimension of at least 100 nanometers or smaller. The small size results in properties that may be substantially different from particles of the same composition in the micrometer scale. It has been demonstrated that the inhalation of hard metal particles may cause an interstitial pulmonary disease and lung cancer, the mechanism of which involves an interaction between Co and WC particles, the generation of reactive oxygen species, and oxidant-induced DNA-damage $(1,2,3,4)$. However, the effect of WC-Co on biologic responses remains to be elucidated. In this study, we analyzed the effects of WC-Co nanoparticles in regulating production of reactive oxygen species (ROS), activation of AP-1, NF-KB, VEGF, AKT or ERK, and angiogenesis. We also tested the effect of fine- and nano-sizes of WC-Co with equal surface area on ROS production and the activation of AKT and ERK.

Results show that WC-Co nanoparticles at $5 \mu \mathrm{g} / \mathrm{cm} 2$ induce ROS production which activates AKT and ERK signaling pathways in lung epithelial cells. ROS also increased transcriptional activation of AP-1, NF- $\mathrm{KB}$, as well as VEGF (via AKT and ERK1/2 activation); while the fine size of WC-Co particles at the same concentration did not have significant effect. However, at high concentrations, fine-size WC-Co particles also induced ROS production, and AKT and ERK1/2 activation. WC-Co nanoparticles also induced angiogenesis in cells. These results identify multiple signaling pathways that are activated by WC-Co nanoparticle treatment, and elucidate the potential molecular mechanisms of their effects on the cells. This information may be useful for preventing potential damage from WC-Co particle exposure in the future. 


\section{Dedication}

I dedicate this dissertation to my parents, Peng Cheng Zhu and Lin Yan Zhu, who gave me so much love, help and encouragement during my study and to my grand parents and friends, whose assistance have encouraged me to fulfill my Master's degree. 


\section{Acknowledgements}

I would like to express my deepest gratitude to my advisor, Dr. Bing-Hua Jiang for his great academic and financial support. His guidance, suggestions and patience have been invaluable to the completion of my dissertation. I deeply appreciate that he gave me the opportunity to finish my Master's study under his supervision.

With respect and gratitude, I wish to thank Dr. Bingyun Li and Dr. Sharon L. Wenger, for their agreeing to be on the committee. Their assistance and critical comments to the research work and dissertation have been very helpful in the completion of the thesis.

I would like to thank every member in the Dr. Bing-Hua Jiang's laboratory. I am especially thankful for the cooperation with Ling-Zhi Liu, Richard Carpenter and Yi Jin. They were very nice and supportive. I will miss the time I spent with them and keep the valuable friendship with them.

Finally, I sincerely thank my parents and my friends with their invaluable love and devotion to me. I could not finish my master's study without their strong support. 


\section{Table of Contents}

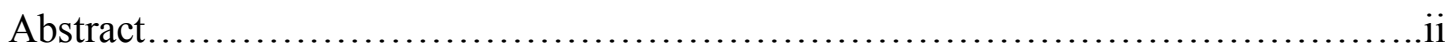

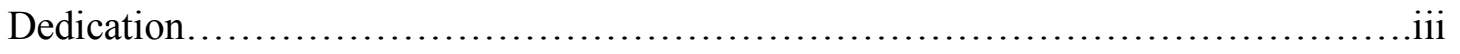

Acknowledgements...........................................................

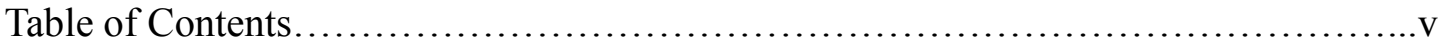

Abbreviation..............................................................viii

\section{Chapter I}

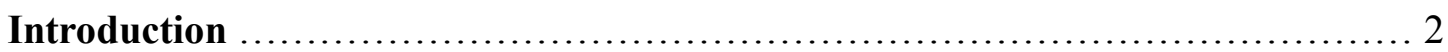

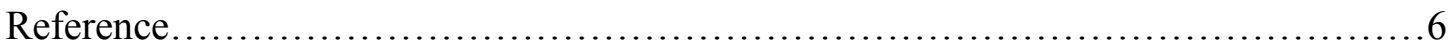

\section{Chapter II}

WC-Co nanoparticles induce ROS production in BEAS-2B cells through NADPH

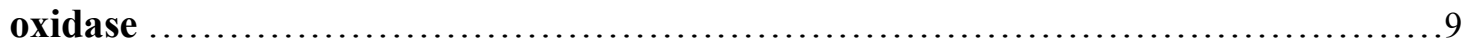

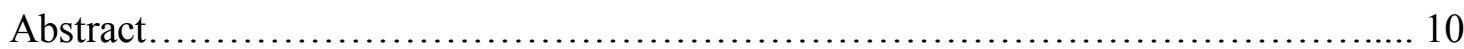

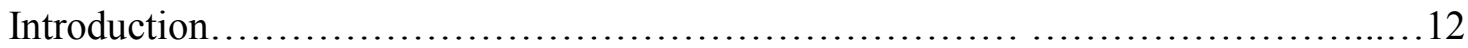

Materials and Methods.......................................................... 14

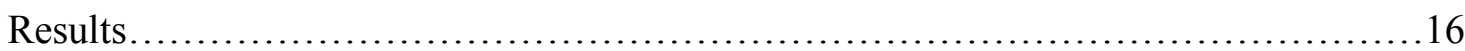

Figures and Legends.......................................................... 19

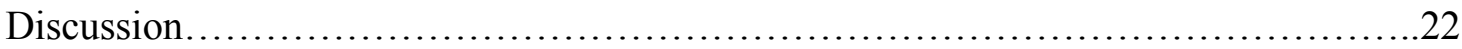

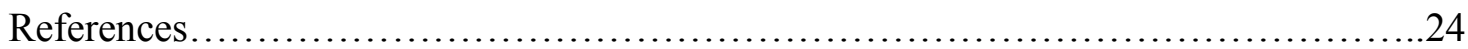




\section{Chapter III}

$\begin{array}{llllll}\text { WC-Co nanoparticles activate AKT and ERK1/2 through ROS } & \text { A }\end{array}$

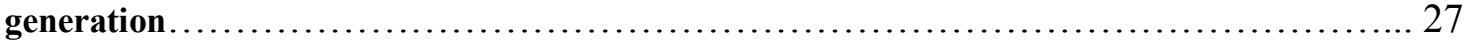

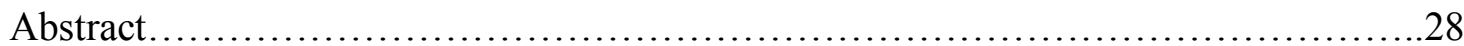

Introduction................................................................... 30

Materials and Methods........................................................ 32

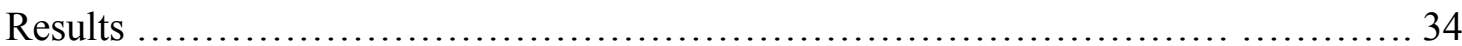

Figures and Legends.......................................................... 36

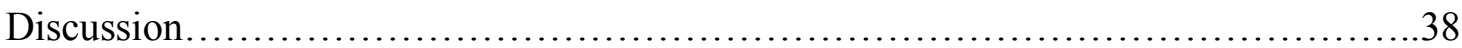

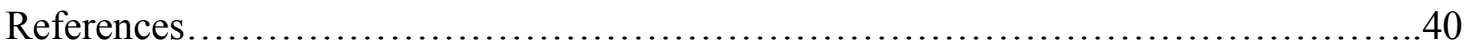

\section{Chapter IV}

WC-Co nanoparticles induced AP-1, NF- $\mathrm{KB}$, and VEGF transcriptional activation

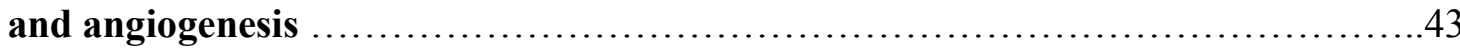

Abstract......................................................................... 44

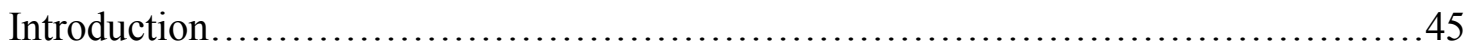

Materials and Methods............................................................. 48

Results ....................................................................... 50

Figures and Legends...................................................... 51

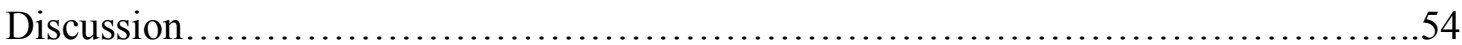


References............................................................... 56

\section{Chapter V}

Discussion and Conclusions.

References................................................................... 72

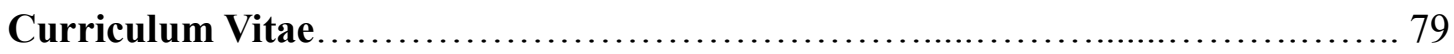




\section{Abbreviations}

$\begin{array}{ll}\text { Ang-1 } & \text { Angiopoietin-1 } \\ \text { AP-1 } & \text { Activator protein-1 } \\ \text { AMPK } & \text { AMP-activated protein kinase } \\ \text { CAM } & \text { Chicken Chorioallantoic Membrane } \\ \text { DCFH-DA } & \text { 2',7'-dichlorofluorescein diacetate } \\ \text { DMSO } & \text { Dimethyl Sulfoxide } \\ \text { DPI } & \text { Diphenylene Iodonium } \\ \text { ERK } & \text { Extracellular Signal Regulated Kinase } \\ \text { Flk-1 } & \text { Fetal liver kinase 1 } \\ \beta-\text {-Gal } & \text { 3-Galactosidase } \\ \text { HER2 } & \text { Human epidermal growth factor receptor 2 } \\ \text { HIF-1 } \alpha & \text { Hypoxia-inducible factor-1 } \alpha \\ \text { JNK } & \text { c-jun N-terminal kinases } \\ \text { MAPK } & \text { Mitogen-Activated Protein Kinase } \\ \text { NF- } \text { KB } & \text { Nuclear factor kappaB } \\ \text { NO } & \text { Nitrogen Oxide } \\ \text { Nox } & \text { NADPH oxidase } \\ \text { PBS } & \text { Phosphate-buffered Saline } \\ \text { PI3K } & \text { Phosphatidylinositol-3-kinase } \\ \text { PTEN } & \text { Phosphatase and tensin homologue } \\ \text { RCAS } & \text { Replication-Competent ASLV long terminal repeat (LTR) with a } \\ & \text { Splice acceptor. } \\ \text { ROS } & \text { Reactive Oxigen Species } \\ \text { SOD } & \text { Superoxide Dismutases } \\ \text { VEGF } & \text { Vascular Endothelial Growth Factors } \\ \text { WC-Co } & \text { Tungsten Carbide-Cobalt }\end{array}$




\section{CHAPTER I}

INTRODUCTION 


\section{Introduction}

Hard metals and nanoparticles:

The first application of cemented carbide using tungsten carbide-cobalt was in the early 1930's. The main components are tungsten carbide (about 90\%) and cobalt metal $(10 \%)$. The development of the mining tools using cemented carbide increased the lifespan of rock drills by a factor of at least ten when compared to steel-based drilling tools. There has been continuous expansion in the cemented carbide application over the last four decades. Currently, cemented carbide hard metals are used in a wide range of products from aerospace, automobile, to home appliances. For these applications, it is important to have the hard metals with the following mechanical properties: hardness, toughness, compressive strength, transverse rupture strength, and wear resistance ${ }^{1}$. The advance in nanotechnology enables us to make various types of hard metal particles. Based on different particle size they can be categorized into: extra coarse, coarse, medium coarse, medium, fine, submicron, ultra fine and nano. There is an increasing interest to use finer and finer cemented carbide particles because it is found that hardness and wear resistance increase with decreasing the size of hard metals. The conventional materials have mutually exclusive hardness and toughness. Nanotechnology is one of the fastest growing and emerging technologies in the US and the world ${ }^{2}$. Nanoparticles are engineered structures with dimension of 100 nanometers or smaller. The properties of materials at this size may substantially differ from the same composition in the micrometer scale. Nanotechnology has a wide-range of applications such as integrated sensors, 
semiconductors, medical imaging, drug delivery, structural materials, sunscreens, cosmetics, and coatings. It is estimated that the global market for nanotechnology-related products will reach $\$ 15$ trillion employing more than 2 million workers in the USA by $2015^{3}$.

It is indicated that the WC-Co nanoparticles have many advantages over the fine particles including the greatly improved toughness, hardness and wear resistance. It is estimated that application of WC-Co nanoparticles is emerging and growing to replace the WC-Co fine particles in various applications and products for improving the mechanical properties of cemented carbide hard metals. Intensive research in nanotechnology will lead to an increased risk of exposure to nanoparticles over the next years. There is a rising public concern over the adverse health effects of exposure to nanoparticles and environmental impact of emerging nanotechnology. Recent evidence indicates that nanoparticles exhibit a higher deposition in all regions of the respiratory tract when compared to the fine particles, and the occupational exposure to nanoparticles may induce cytotoxicity, pulmonary inflammation, and/or other adverse effects in the lung ${ }^{4,5,6}$. Once deposited in the airways, nanoparticles migrate more rapidly to the interstitium, lymph nodes and lung than the fine particles ${ }^{7}$.

Exposure to nanoparticles and potential toxicity:

People can get exposed to nanostructures via a variety of sources, such as the manufacture of the nanoparticles, the injection with nanoparticles, as well as the usage of products containing nanoparticles. It has been demonstrated that the overall 
behavior of inhaled nanoparticles could be summarized in three steps: (a) nanoparticles can enter the body via six principle manners: intra venous, dermal, subcutaneous, inhalation, intraperitoneal, and $\mathrm{oral}^{8}$, (b) afterward, they can be absorbed by interaction with biological components (proteins, cells), and distribute to various organelles in the body, during which, they may retain the same structure, be modified, or be metabolized, (c) finally, they enter the cells and reside in the cells for an unknown period of time or until their excretion ${ }^{9}$.These emerging new materials could have several possible modes of toxicity: (a) nanoparticles could have unique electronic, optical, and magnetic properties due to their special physical dimensions, and it is difficult to predict the toxic effect of the breakdown of nanoparticles ${ }^{10}$; (b) the surface of nanoparticles is involved in a number of catalytic and oxidative reactions; if these reactions turn out to be cytotoxic, the toxicity could be greater than their bulk material counterpart because of much greater surface area-to-volume ratio, (c) nanoparticles contain metals or compounds with known toxicity, thus their breakdown could lead to similar toxic responses as their components ${ }^{11}$.

There is concern that environmental or occupational exposures to nanoparticles will be a major public health issue ${ }^{12}$.However, the health and safety regulatory structures do not understand yet the extent and potential toxicity of nanoparticles in the environment and workplace. The effects of WC-Co nanoparticles and other nanoparticles in the cells and animals are not known yet. It has been found that WC-Co nanoparticles increased ROS generation, activated several signaling molecules, and induced angiogenesis ${ }^{13}$. Many questions remain to be answered such 
as the specific type of ROS induced by the nanoparticles, mechanism of ROS induction, the connection of ROS production to signaling pathway activation in the cells and biological responses such as nanoparticle-induced angiogenesis.

Many studies demonstrated that tungsten carbide cobalt (hard metal) fine-sized and nano-sized particles induce high levels of $\operatorname{ROS}^{14,15}$. 
Reference List

1. P. Ettmayer. HARDMETALS AND CERMETS. Annu. Rev. Maler. Sci., 19:145-154,1989.

2. Bleeker, Ronald A. Patenting Nanotechnology. Materials Today, 2004.

3 U.S. Envirpmental Protecton Agency. International perspective on environmental nanotechnology application and implications. Volume 1, 2008.

4. Bujak-Pietrek S. Occupational exposure to nanoparticles. Assessment of workplace exposure.Med Pr.,61:183-189, 2010.

5. Hayes A, Bakand S. Inhalation toxicology.100:461-488, 2010.

6. Zolnik BS, González-Fernández A, Sadrieh N, Dobrovolskaia MA. Nanoparticlesand the immune system. Endocrinology, 151:458-465, 2010.

7. G. Oberdorster, V. Stone and K. Donaldson. Toxicology of nanoparticles: a historical perspective. Nanotoxicology, 1:2-25, 2007.

8. J.P. Ryman-Rasmussen, J.E. Riviere and N.A. Monteiro-Riviere. Variables influencing interactions of untargeted quantum dot nanoparticles with skin cells 
and identification of biochemical modulators. Nano Lett.,7 :1344-1348,2007.

9. P. Borm, F.C. Klaessig, T.D. Landry, B. Moudgil, J. Pauluhn, K. Thomas, R. Trottier and S. Wood. Research strategies for safety evaluation of nanomaterials, part V: role of dissolution in biological fate and effects of nanoscale particles. Toxicol Sci, 90:23-32, 2006.

10. A. Nel, T. Xia, L. Maedler and N. Li. Toxic potential of materials at the nanolevel. Science, 311:622-627, 2006.

11. T. Xia, M. Kovochich, J. Brant, M. Hotze, J. Sempf, T. Oberley, C. Sioutas, J.I. Yeh, M.R. Wiesner and A.E. Nel. Comparison of the abilities of ambient and manufactured nanoparticles to induce cellular toxicity according to an oxidative stress paradigm. Nano Lett., 6:1794-1807,2006.

12. G. Oberdorster, E. Oberdorster and J. Oberdorster. Nanotoxicology: an emerging discipline evolving from studies of ultrafine particles. Environ Health Perspect., 113:823-839,2005.

13. Zhang XD, Zhao J, Bowman L, Shi X, Castranova V, Ding M. Tungsten carbide-cobalt particles activate Nrf2 and its downstream target genes in JB6 cells possibly by ROS generation. J Environ Pathol Toxicol Oncol., 29:31-40, 
2010.

14. Fenoglio I, Corazzari I, Francia C, Bodoardo S, Fubini B. The oxidation of glutathione by cobalt/tungsten carbide contributes to hard metal-induced oxidative stress. Free Radic Res., 42:437-745,2008.

15. Lison D, Carbonnelle P, Mollo L, Lauwerys R, Fubini B. Physicochemical mechanism of the interaction between cobalt metal and carbide particles to generate toxic activated oxygen species. Chem Res Toxicol., 8:600-606,1996. 


\section{CHAPTER II}

WC-Co nanoparticles induce ROS production in BEAS-2B cells through NADPH oxidase 


\begin{abstract}
Studies have shown that the association of tungsten carbide (WC) and metallic cobalt (Co) increases reactive oxygen species (ROS) production ${ }^{1}$. Recently, some reviews have concluded that the toxic effects of inhaled heavy metal nanoparticles are associated with the oxidative stress by the increasing generation of reactive oxygen species $(\mathrm{ROS})^{2}$. Based on these reports, we hypothesize that WC-Co nanoparticles may also induce ROS in cells. To test whether the hard metal WC-Co nanoparticles induce ROS production in lung epithelial cells, we measured the production of ROS in cultured BEAS-2B cells treated with WC-Co nanoparticles at different time durations. We found that WC-Co nanoparticles strongly induced ROS production in BEAS-2B cells. Increase in ROS by nanoparticles was observed 15 minutes after the treatment, and reached higher levels 2 hours after the treatment.
\end{abstract}

To further determine which species of ROS are generated by the exposure to WC-Co nanoparticles, we pretreated cells with the hydrogen peroxide $\left(\mathrm{H}_{2} \mathrm{O}_{2}\right)$ scavenger (catalase). Treatment with catalase inhibited ROS production, suggesting that $\mathrm{H}_{2} \mathrm{O}_{2}$ is one of the species of ROS generated by nanoparticles. To determine what signaling molecules are required for ROS production by WC-Co nanoparticles, we specifically tested the involvement of membrane-bound NADPH oxidase, AKT and ERK. BEAS-2B and JB6 cell lines (mouse lung epidermal cell lines) were pretreated with NADPH-dependent oxidase inhibitor (DPI), PI3K inhibitor (LY294002) and MEK inhibitor (U0126), then exposed to nanoparticles. Our results show that 
ROS generation was inhibited by diphenylene iodonium (DPI) and catalase, but not LY294002 and U0126, suggesting that NADPH oxidase is the source of the nanoparticle-induced ROS production in both cell lines.

WC-Co hard metal dust is composed of tungsten carbide (WC) and metallic cobalt particles (Co). It has been pointed out that one possible mechanism underlying the higher toxicity of WC-Co particles compared with Co or WC alone is the specific physicochemical interaction between $\mathrm{Co}$ and WC particles, which leads to the enhanced short-term formation of $\operatorname{ROS}^{3,4}$. Thus, we hypothesize that not only nano-sized but also fine-sized WC-Co may induce ROS generation in cells. Compared to fine-sized WC-Co particles, the nanoparticles have much higher surface area (17.1 times) ${ }^{5}$. To test whether WC-Co fine-sized particles also induce ROS generation, we measured the ROS produced at high concentration of WC-Co fine-sized particles. We found that $85.5 \mu \mathrm{g} / \mathrm{cm} 2$ of the fine-sized particles(same surface area of $5 \mu \mathrm{g} / \mathrm{cm} 2$ of the nanoparticles) produced only $35 \%$ ROS of the nanoparticle treatment with the same surface area, which is $75 \%$ less than nanoparticle induced ROS generation.

Our data suggested that 1) the level of ROS production is partially associated with the surface area of WC-Co particles and that nanoparticles are more potent in inducing ROS in the cells; 2) NADPH oxidase is required for nanoparticle-induced ROS production in the cells. 


\section{INTRODUCTION}

Reactive oxygen species (ROS) refers to a diverse group of reactive, short-lived chemically-reactive molecules which contain oxygen. ROS include superoxide (O2--), hydroxyl radical $(\cdot \mathrm{OH})$, hydrogen peroxide $\left(\mathrm{H}_{2} \mathrm{O}_{2}\right)$ and peroxynitrite(ONOO- $)^{6}$. In normal cells, low levels of ROS are produced by all aerobic organisms through the oxygen reduction process; they are generated either endogenously from mitochondria, metabolic processes, inflammation etc. or from external sources. Increased levels of ROS are induced by growth factors and cytokines and are important for cancer cell proliferation and tumor development ${ }^{7}$. ROS are produced from a number of sources including the mitochondrial electron transport system, xanthine oxidase, cytochrome p450, NADPH oxidase, as well as uncoupled NO synthase (NOS) and MPO ${ }^{8}$. Recent studies indicated that NADPH oxidases, also known as Nox enzymes, emerged as major sources of ROS induction, and may play an important role in ROS generation in some cancer cells. Nox enzymes consist of catalytic subunits (Nox1, Nox2, Nox4, Nox5) and cytosolic regulatory subunits (p47phox, p67phox, the small GTPase Rac1) ${ }^{9,10}$. Cells have developed a variety of enzymatic and non-enzymatic mechanisms to defend themselves against damage resulting from oxidative stress, including antioxidant defenses through glutathione and antioxidant enzymes. The most important antioxidant enzymes include the superoxide dismutases $\left(\mathrm{SOD}^{-1}\right.$ and SOD ${ }^{-2}$ ), which catalyze $\mathrm{O}_{2} \cdot{ }^{-}$to $\mathrm{H}_{2} \mathrm{O}_{2}$ and $\mathrm{H}_{2} \mathrm{O}$; catalase, which catalyzes $\mathrm{H}_{2} \mathrm{O}_{2}$ to $\mathrm{O}_{2}$

and $\mathrm{H}_{2} \mathrm{O}$; and glutathione peroxidase which converts $\mathrm{H}_{2} \mathrm{O}_{2}$ to $\mathrm{H}_{2} \mathrm{O}^{11,12,13}$. Tumor cells show elevated ROS content compared to normal cells in numerous current reports; 
moreover, the endogenous ROS are reported to be important in controlling tumor cell growth. In fact, emerging evidence has shown that reactive oxygen species (ROS) contribute to carcinogenesis and the malignant progression of tumor cells in different ways: they act as cell signaling intermediates to drive genomic damage and genetic instability, promote cell motility, shape the tumor microenvironment by inducing inflammation and inducing angiogenesis. It has been suggested recently that the adverse and toxic effects of inhaled nanoparticles may be associated with the oxidative stress induced by the increasing generation of ROS. Thus, we will investigate which types of ROS are formed by the exposure to $\mathrm{WC}-\mathrm{Co}$; what signaling pathways are involved in ROS generation; we will specifically test the involvement of membrane-bound NADPH, and the role of PI3K and ERK1/2 in ROS production, furthermore, we will study the effect of fine-sized particle in ROS production. 


\section{Materials and methods}

\section{Chemical Reagents}

Catalase was purchased from SIGMA-ALDRICH( St Louis), U0126, LY294002 and diphenylene iodonium (DPI) were obtained from Calbiochem (La Jolla, CA). Dulbecco's Modified Eagle Medium (DMEM) was purchased from Mediatech,Inc(Manassas,VA.). Eagle's minimal essential medium (MEM) and phosphate-buffered saline (PBS) were purchased from Whittaker Biosciences (Walkersville, MD). Fetal bovine serum (FBS), gentamicin and l-glutamine were from Life Technologies, Inc. (Gaithersburg MD). 2',7'-dichlorofluorescein diacetate (DCDF-DA) and dihydroethidium were obtained from Molecular Probes (Eugene, OR).

\section{Cell culture}

The human bronchial endothelial cell line BEAS-2B was grown in DMEM supplemented with $10 \%$ heat inactivated fetal bovine serum, $2 \mathrm{mM}$ L-glutamine, $0.2 \%$ insulin, $100 \mathrm{U} / \mathrm{ml}$ penicillin, and $100 \mu \mathrm{g} / \mathrm{ml}$ streptomycin, and cultured at $37^{\circ} \mathrm{C}$ in humidified 5\% $\mathrm{CO}_{2}$ incubator. The mouse lung epidermal cell line JB6 was cultured in Eagle's MEM, containing 5\% heat inactivated fetal bovine serum, $2 \mathrm{mM}$ L-glutamine, and $50 \mu \mathrm{g}$ of gentamicin $/ \mathrm{ml}$.

WC-Co Particles preparation 
Nano-sized WC-Co, with average particle size $80 \mathrm{~nm}$, were obtained from Inframat Advanced Materials, Farmington, CT. (Purity of the nanoparticles was 99.9\%). These nanoparticles were WC and Co molecularly mixed, with $15 \%$ of Co, fine $\mathrm{WC}-$ Co particles, with average size $4 \mu \mathrm{m} \quad$ were $\mathrm{WC}$ and Co molecularly mixed, with $6 \%$ of Co were purchased from Alfa AESAR (A Johnson Mattey Company, Ward Hill, MA), with purity of the fine particles at $99.9 \%$. The suspensions of nanoor fine-sized WC-Co were prepared by sonication with PBS to disperse the particles using a Branson Sonifier 450 (Danbury, CT) for 2-3 min prior to exposure.

Intracellular hydrogen peroxide $\left(\mathrm{H}_{2} \mathrm{O}_{2}\right)$ detection

BEAS-2B cells were seeded on coverslips in a 6-well plate, and cultured overnight. Cells were maintained in the presence or absence of $5 \mu \mathrm{g} / \mathrm{cm}^{2}$ fine- or nano-sized WC-Co for the indicated time period, followed by incubation with $5 \mu \mathrm{M}$ 2',7'-dichlorofluorescein diacetate (DCFH-DA) for $15 \mathrm{~min}$. The cells were washed twice with phosphate-buffered saline (PBS), and fixed with 10\% buffered formalin for $10 \mathrm{~min}$. The fluorescent images were captured using a confocal fluorescence microscope. In order to test the effects of catalase, LY294002, or U0126, cells were pre-treated with these reagents for $30 \mathrm{~min}$, particles were added and cells were subsequently treated as above. 


\section{RESULTS}

WC-Co nanoparticles induced ROS production in BEAS-2B cells

To measure the production of ROS in cultured BEAS-2B cells treated with WC-Co nanoparticles, the cells were seeded on the cover-slip the night before the treatment, then treated either with solvent, the fine-sized or nano-sized particles. The results indicate that the nano-size particles induced high levels of ROS production in the cells; this was not observed in the control and the fine-size particle group (Fig. 1). The effect of the nanoparticles in inducing ROS production was observed as early as 15 min after the treatment, and reached highest levels at 2 hours after the treatment (Fig. 2). These data demonstrate that WC-Co nanoparticles strongly induce ROS production in BEAS-2B cells.

The ROS production was inhibited by diphenylene iodonium (DPI) and catalase

The Beas-2B cells were cultured as described above. The cells were pretreated with DPI (NADPH oxidase inhibitor) and catalase, the hydrogen peroxide $\left(\mathrm{H}_{2} \mathrm{O}_{2}\right)$ scavenger; followed by treatment with nanoparticles. The ROS production was inhibited by DPI and catalase treatment (Fig. 3.A). PI3K inhibitor LY294002 and MEK inhibitor U0126 did not inhibit the ROS generation (Fig. 3.B). This result suggested that NADPH oxidase is required for the nanoparticle-induced ROS production in the cells. 
WC-Co nanoparticles induced ROS production in JB6 cells; ROS production was inhibited by catalase and DPI

The JB6 cells were cultured on the cover-slip, and treated with solvent, the fine-sized or nano-sized particles in the absence or presence of catalase or DPI as described in Fig. 4. The nanoparticles, but not the fine particles, induced ROS production in JB6 cells. The induction of ROS could be inhibited by the addition of catalase or DPI (Fig. 4). These results demonstrate that nanoparticles have similar effects in two different cell lines with respect to inducing ROS generation.

High concentrations of WC-Co fine particles also induced ROS production in BEAS-2B cells

The nanoparticles have much higher surface area -around 17.1 times higher than fine particles. To test whether high concentrations of WC-Co fine particles may also induce ROS production, BEAS-2B cells were treated with $28.5,57$, or $85.5 \mu \mathrm{g} / \mathrm{cm} 2$ of the fine particles for $30 \mathrm{~min}$. The cells treated with the solvent or $5 \mu \mathrm{g} / \mathrm{cm} 2 \mathrm{WC}-\mathrm{Co}$ nanoparticles were used as the negative and positive controls, respectively. The results indicated that the increasing amount of fine particles induced higher levels of ROS production in the cells, and $85.5 \mu \mathrm{g} / \mathrm{cm} 2$ of the fine particles, which has the same surface area as $5 \mu \mathrm{g} / \mathrm{cm} 2$ of the nanoparticles, produced $35 \%$ ROS levels of the nanoparticle treatment (Fig. 5). This result demonstrates that 1) ROS production is partially associated with the surface area of WC-Co particles; 2) the nanoparticles are 
more potent in inducing the ROS; and 3) high concentrations of WC-Co fine particles can also induce the ROS production. 


\section{Figures and Legends}

Fig.1. WC-Co nanoparticles induce ROS production

Control
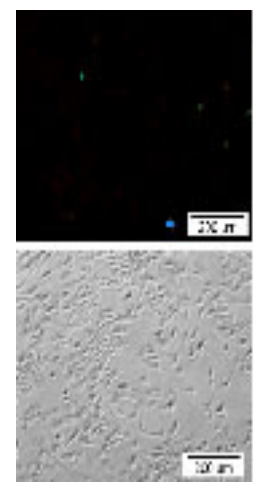

Fine
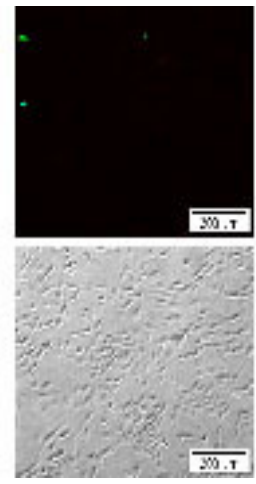

Nano

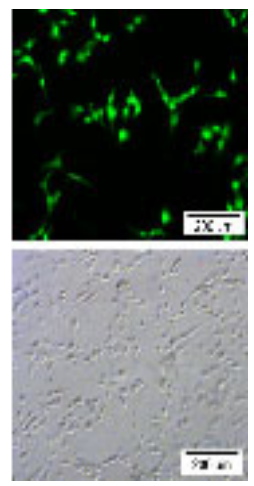

Fig.1. WC-Co nanoparticles induce ROS production. BEAS-2B cells were plated on a glass slip in the 6-well plate, and incubated at $37^{\circ} \mathrm{C}$ for $24 \mathrm{~h}$. The cells were then cultured in serum-free medium with fine-size or nano-size WC-Co particles at $5 \mu \mathrm{g} / \mathrm{cm}^{2}$ for $30 \mathrm{~min}$. DCFH-DA $(5 \mu \mathrm{M})$ was added and incubated with the cells for $15 \mathrm{~min}$. Then, the cells were washed and fixed. The images were captured with a fluorescence microscope. The fluorescent images were captured using a confocal microscope (upper panel). The corresponding phase micrographs are shown in the bottom panel. Bar: $200 \mu \mathrm{m}$.

Fig.2. Effects of WC-Co nanoparticles at $5 \mu \mathrm{g} / \mathrm{cm} 2$ on ROS production at different time-points.

$0 \mathrm{~min}$
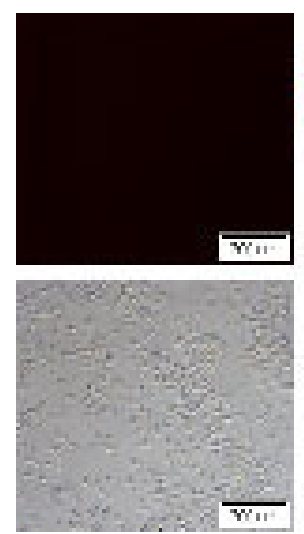

$15 \mathrm{~min}$
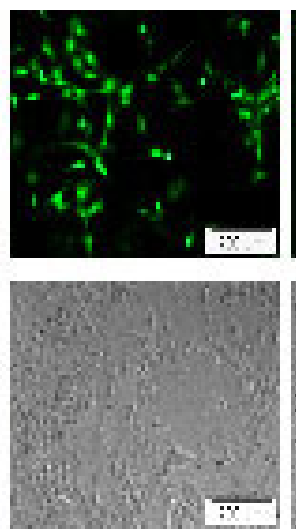

$30 \mathrm{~min}$
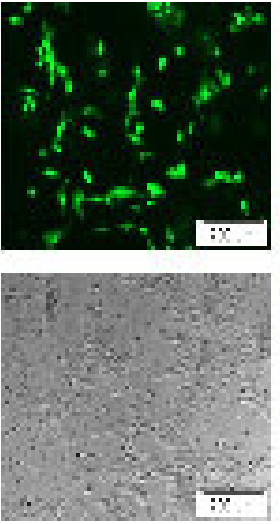

$1 \mathrm{~h}$
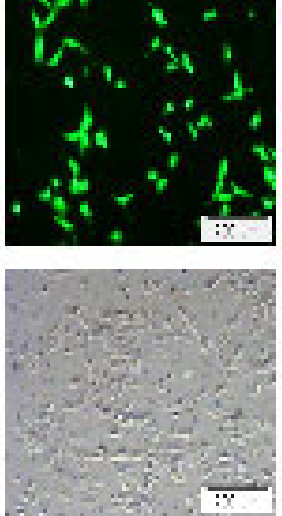

$2 \mathrm{~h}$
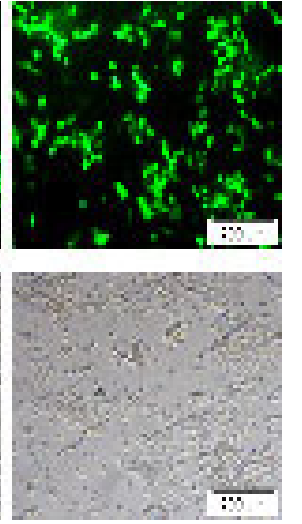

Fig.2. Effects of WC-Co nanoparticles at $5 \mu \mathrm{g} / \mathrm{cm}^{2}$ on ROS production at different time-points. BEAS-2B cells were plated on a glass slip in the 6 -well plate, and incubated at $37^{\circ} \mathrm{C}$ for $24 \mathrm{~h}$. The cells were then cultured in serum-free medium in the presence of nanoparticles at $5 \mu \mathrm{g} / \mathrm{cm}^{2}$ for time periods as indicated. DCFH-DA $(5 \mu \mathrm{M})$ was added and incubated with the cells for $15 \mathrm{~min}$. Then the cells were washed and fixed, and the images were captured as above. The fluorescent images were captured using a confocal 
microscope (upper panel). The corresponding phase micrographs are shown in the bottom panel. Bar: $200 \mu \mathrm{m}$.

Fig.3. Catalase and DPI treatment inhibited ROS production induced by the nanoparticles.

A

Control
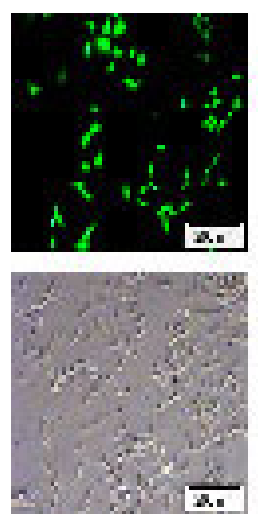

Catalase
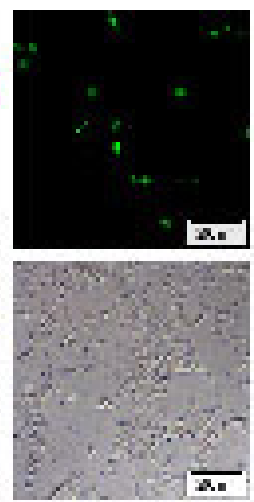

$\mathrm{B}$

DPI
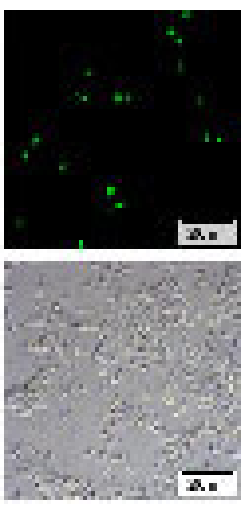

Control
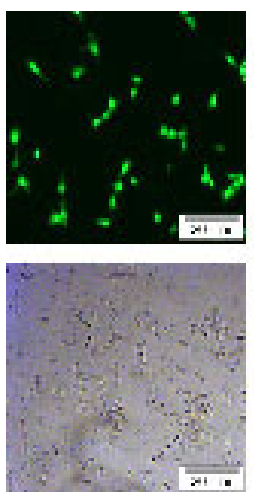

LY
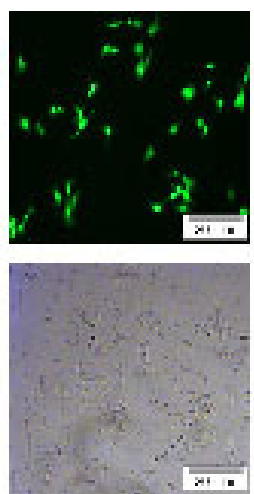

U0126
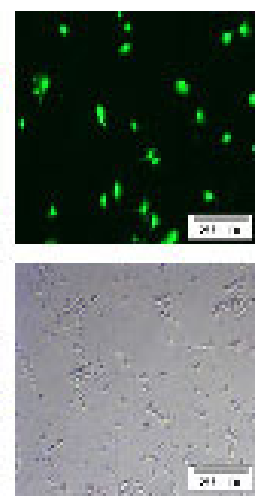

Fig.3. Catalase and DPI treatment inhibited ROS production induced by the nanoparticles. BEAS-2B cells were plated on a glass coverslip in the 6-well plate, and incubated at $37^{\circ} \mathrm{C}$ for $24 \mathrm{~h}$. The cells were then cultured in serum-free medium without or with $2000 \mathrm{U} / \mathrm{ml}$ catalase or $5 \mu \mathrm{M}$ DPI (A); $10 \mu \mathrm{M} \mathrm{LY} 294002$ or $10 \mu \mathrm{M} \cup 0126$ (B) for $1 \mathrm{~h}$. Then cells were treated with 5 $\mu \mathrm{g} / \mathrm{cm}^{2}$ WC-Co nanoparticles for $30 \mathrm{~min}$. DCFH-DA was added to the cells, and fluorescent images were obtained as above. $A$, Catalase and DPI inhibited ROS production. $B$, LY294002 and U0126 did not have effect on ROS production.

Fig.4. The induction of ROS was inhibited by the addition of catalase and DPI in JB6 cell lines

Control
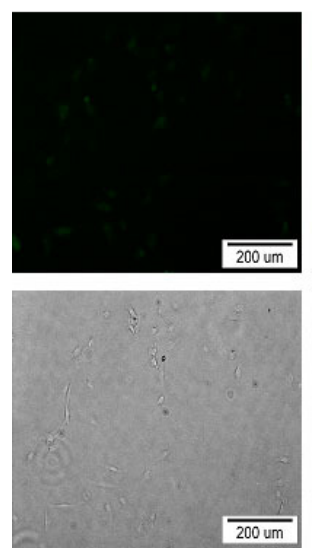

Fine
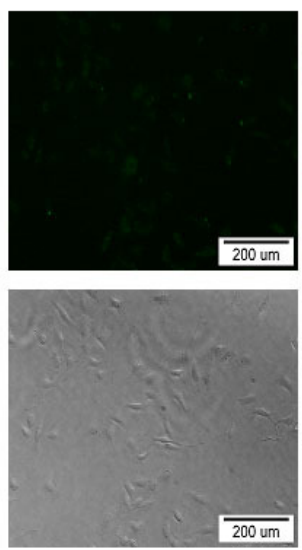

Nano
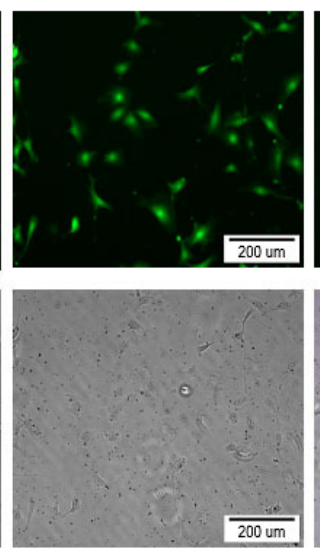

Catalase
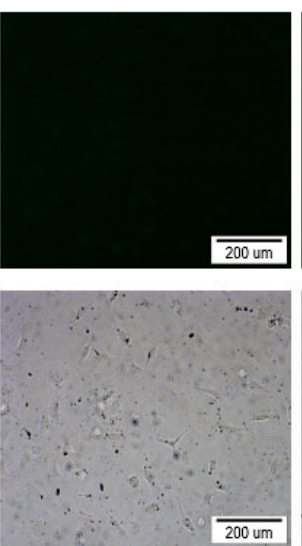

DPI
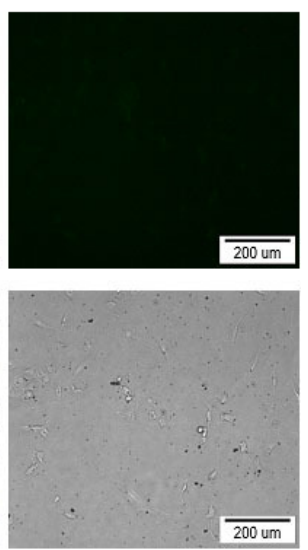
Fig.4. JB6 cells were plated onto a glass slip in the 6-well plate, and incubated at $37^{\circ} \mathrm{C}$ for $24 \mathrm{~h}$. Some cells were pretreated with $2000 \mathrm{U} / \mathrm{ml}$ catalase or $5 \mu \mathrm{M}$ DPI in medium containing $0.1 \%$ FBS for $1 \mathrm{~h}$. Then cells were incubated without or with fine-size or nano-size WC-Co particles at $5 \mu \mathrm{g} / \mathrm{cm}^{2}$ for $30 \mathrm{~min}$. DCFH-DA $(5 \mu \mathrm{M})$ was added and incubated with the cells for $15 \mathrm{~min}$. Then the cells were washed and fixed. The images were captured with a fluorescent microscope. The fluorescent images were captured using a confocal microscope (up panel). The corresponding phase micrographs were shown in the bottom panel. Bar: $200 \mu \mathrm{m}$.

Fig.5. High concentrations of WC-Co fine particles also induced ROS production

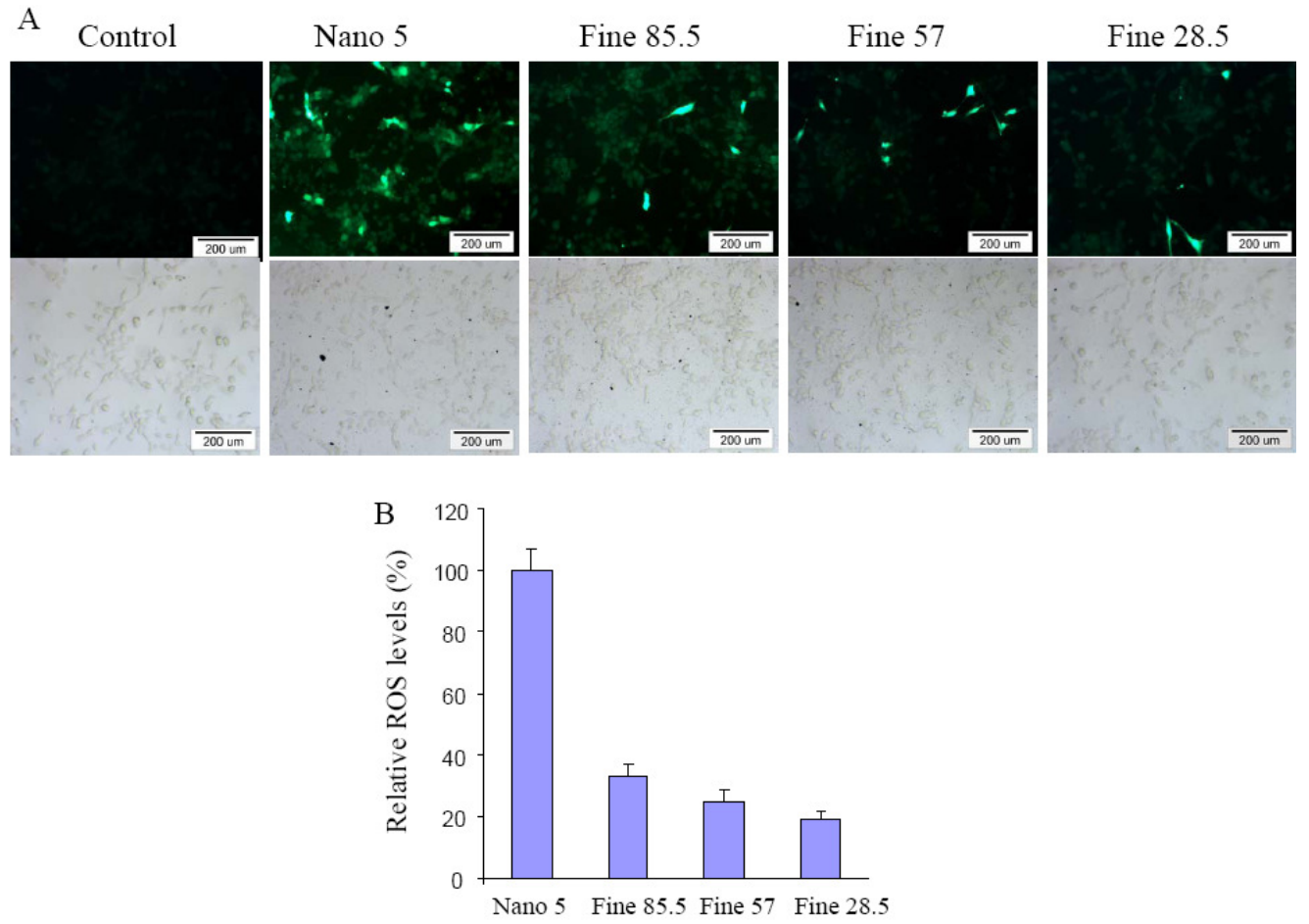

Fig.5. High concentrations of WC-Co fine particles also induced ROS production. BEAS-2B cells were plated on a glass slip in the 6-well plate, and incubated at $37^{\circ} \mathrm{C}$ for $24 \mathrm{~h}$. The cells were then cultured in serum-free medium with fine-size WC-Co particles at 28.5, 57, or 85.5 $\mu \mathrm{g} / \mathrm{cm}^{2}$ for $30 \mathrm{~min}$. The cells treated with solvent (control) or $5 \mu \mathrm{g} / \mathrm{cm}^{2}$ nanoparticles were used as negative or positive control. DCFH-DA $(5 \mu \mathrm{M})$ was added and incubated with the cells for $15 \mathrm{~min}$. The cells were washed and fixed. The ROS signals were captured with a fluorescence microscope (Fig. 6A). The corresponding phase micrographs were shown on the bottom panel. Bar: $200 \mu \mathrm{m}$. The ROS signals were quantified using a confocal microscope from 6 replicate slides (Fig. 6B). 


\section{DISCUSSION}

Several studies have demonstrated that ROS production by heavy metal WC-Co appears to be dependent on the physical and chemical properties of the particles, such as particle size, dissolution behavior, surface reactivity and binding ability ${ }^{14}$. In this study, we found that although fine-sized particles also induce ROS production, it is $75 \%$ less than nanoparticles with the same surface area; this may be due to the greater surface area-to-volume ratio of nanoscale material, and it also suggests that particle size of WC-Co has significant effect on ROS production.

We further found that the induction of ROS by nanoparticles increased with time, and reached the highest level after 2 hours of nanoparticle treatment, however, it is interesting to investigate ROS level at longer time points to get a general idea of the pattern of time-dependent ROS induction. To study the biological mechanism how nano-sized or fine- sized WC-Co particles increase ROS production, we co-treated cells with NADPH-dependent oxidase inhibitor DPI, the hydrogen peroxide $\left(\mathrm{H}_{2} \mathrm{O}_{2}\right)$ scavenger catalase, PI3K inhibitor LY294002, MEK inhibitor U0126 and nanoparticles. Results show that ROS production was inhibited by DPI and catalase, but not U0126 and LY294002, which suggests that hydrogen peroxide $\left(\mathrm{H}_{2} \mathrm{O}_{2}\right)$ is one of the ROS types generated by nanoparticles via NADPH oxidase activity, but not via AKT and ERK.

Although PI3K inhibitor and MEK inhibitor did not influence ROS production, these two pathways may act as the downstream signaling mediators of ROS. We 
found the WC-Co nanoparticles induced ROS generation in both BEAS-2B cells and JB6 cells, this suggested that fine or ultra fine particles of WC-Co induced ROS generation in two different cell types. 


\section{Reference List}

1. Zhang XD, Zhao J, Bowman L, Shi X, Castranova V, Ding M. Tungsten carbide-cobalt particles activate Nrf2 and its downstream target genes in JB6 cells possibly by ROS generation. J Environ Pathol Toxicol Oncol., 29:31-40, 2010.

2. D Lison, P Carbonnelle, L Mollo, R Lauwerys and B. Fubini. Physicochemical mechanism of the interaction between cobalt metal and carbide particles to generate toxic activated oxygen species. Chem. Res. Toxicol., 8: 600-606, 1995.

3. Lison,D. and Lauwerys, R. The interaction of cobalt metal with different carbides and other mineral particles on mouse peritoneal macrophages. Toxicol., 9: 341-347, 1995.

4. De Boeck M, Lombaert N, De Backer S, Finsy R, Lison D, Kirsch-Volders M.. In vitro genotoxic effects of different combinations of cobalt and metallic carbide particles. Mutagenesis., 18:177-186, 2003.

5. Ding M, Kisin ER, Zhao J, Bowman L, Lu Y, Jiang B, Leonard S, Vallyathan V, Castranova V, Murray AR, Fadeel B, Shvedova AA. Size-dependent effects of tungsten carbide-cobalt particles on oxygen radical production and activation of cell signaling pathways in murine epidermal cells. Toxicol Appl Pharmacol. , 
241:260-268, 2009.

6. Klaunig JE, Kamendulis LM. The role of oxidative stress in carcinogenesis. Annu Rev Pharmacol Toxicol., 44:239-67, 2004.

7. Alexis Laurent, Carole Nicco, Christiane Chéreau, Claire Goulvestre, Jérôme Alexandre, Arnaud Alves4, Eva Lévy, Francois Goldwasser, Yves Panis, Olivier Soubrane, Bernard Weill, and Frédéric Batteux. Controlling Tumor Growth by Modulating Endogenous Production of Reactive Oxygen Species. Cancer Res.,65:948-56,2005.

8. Valko M, Leibfritz D, Moncol J, Cronin MT, Mazur M, Telser J. Free radicals and antioxidants in normal physiological functions and human disease. Int $\mathbf{J}$ Biochem Cell Biol.,39:44-84, 2007.

9. Paravicini TM, Touyz RM. NADPH oxidases, reactive oxygen species, and hypertension: clinical implications and therapeutic possibilities. Diabetes Care.,31 Suppl., 2:170-180, 2008.

10. Sedeek M, Hébert RL, Kennedy CR, Burns KD, Touyz RM. Molecular mechanisms of hypertension: role of Nox family NADPH oxidases. Curr Opin Nephrol Hypertens., 18:122-127, 2009. 
11. Valdivia A, Pérez-Alvarez S, Aroca-Aguilar JD, Ikuta I, Jordán J. Superoxide dismutases: a physiopharmacological update. J Physiol Biochem., 2:195-208, 2009.

12. Heck DE, Shakarjian M, Kim HD, Laskin JD, Vetrano AM. Mechanisms of oxidant generation by catalase. Ann N Y Acad Sci., 1203:120-125, 2010.

13. Marí M, Morales A, Colell A, García-Ruiz C, Fernández-Checa JC.

Mitochondrial glutathione, a key survival antioxidant. Antioxid Redox Signal., $11: 2685-700,2009$.

14. Bastian S, Busch W, Kühnel D, Springer A, Meissner T, Holke R, Scholz S, Iwe M, Pompe W, Gelinsky M, Potthoff A, Richter V, Ikonomidou C, Schirmer K.Toxicity of tungsten carbide and cobalt-doped tungsten carbide nanoparticles in mammalian cells in vitro. Environ Health Perspect., 117:530-536.2009. 


\section{CHAPTER III}

WC-Co nanoparticles activate AKT and ERK1/2 through ROS generation 


\begin{abstract}
We found in our preliminary studies that ROS generation induced by WC-Co nanoparticles was inhibited by DPI, but not U0126 and LY294002, indicating that NADPH oxidase, but not PI3K/AKT and MEK/ERK pathways, are required for nanoparticle-induced ROS production. However, we hypothesized that ROS may act as the upstream regulator of AKT and ERK1/2, to test this hypothesis, we first determined whether WC-Co nanoparticles affect AKT and extracellular signal-regulated kinase (ERK) activation. BEAS-2B cells were treated with the nano-size or fine-size WC-Co particles, and activation of AKT and ERK1/2 was analyzed by Western blotting. The nanoparticles were found to induce AKT and ERK1/2 activation at the low concentration of $2.5 \mu \mathrm{g} / \mathrm{cm}^{2}$ which increased with higher doses, while fine particles of WC-Co had only modest effect even at high concentrations $(50 \mu \mathrm{g} / \mathrm{cm} 2)$. Further, we wanted to determine whether ROS may be the upstream regulator of AKT and ERK. The cells treated as above were analyzed for the activation of AKT and ERK by immunoblotting. Treatment with catalase inhibited levels of both phospho-AKT and phospho-ERK. As a control, LY294002 and U0126 decreased WC-Co nanoparticle-induced AKT and ERK activation, respectively. These results indicate that WC-Co nanoparticles regulate AKT and ERK pathways through ROS production.
\end{abstract}

High concentration of WC-Co fine particles can also induce ROS generation (as indicated in chapter 1), thus, it is tempting to test whether high concentrations of 
WC-Co fine particles can also induce AKT and ERK1/2 activation. Our results show that $57 \mu \mathrm{g} / \mathrm{cm} 2$ and $85.5 \mu \mathrm{g} / \mathrm{cm} 2$ fine-sized WC-Co particles induced AKT and ERK1/2 activation in cells, and that increasing concentrations of WC-Co fine particles were associated with higher levels of AKT and ERK1/2 activation. However, the levels of AKT and ERK1/2 activation induced by $85.5 \mu \mathrm{g} / \mathrm{cm} 2$ fine-sized WC-Co particles were not as high as those achieved by $5 \mu \mathrm{g} / \mathrm{cm}^{2}$ WC-Co nanoparticles, suggesting that the WC-Co fine-sized particles at high concentrations are also able to induce AKT and ERK1/2 activation, but not as strongly as nano-sized particles. This is consistent with their effect on ROS generation in cells compared to nano-sized particles. 


\section{INTRODUCTION}

The mitogen-activated protein kinases (MAPK) are a large family of serine/threonine kinases that require tyrosine and threonine phosphorylation for activation through MAPK cascades, which involve a core of three protein kinases: MAP kinase kinase kinase(MAPKKK), MAP Kinase Kinase(MAPKK) and MAP Kinase(MAPK) ${ }^{1,2}$. Based on different motifs in the activation loop, MAPKs are classified into: extracellular signal regulated kinases (ERKs), c-jun N-terminal kinases (JNKs) and p38 MAPKs. The ERKs mainly regulate proliferation and differentiation, while the JNKs and p38MAP kinases are associated with responses to cellular stresses $^{3,4}$. ERK1/2 are part of a mitogen-activated protein kinase (MAPK) cascade consisting of sequentially functioning kinases-Raf, MEK (MAPKK) and ERK1/2 $(\mathrm{MAPK})^{5}$. Active ERK1/2 induce reprogramming of gene expression by phosphorylating various intracellular target proteins and transcription factors and thereby initiate cell growth, proliferation, differentiation and anti-apoptotic effects ${ }^{6}$. Recently, rapidly growing evidence suggested that increased ROS levels can also activate MEK/ERK pathway ${ }^{7}$.

The phosphoinositide 3-kinases (PI3Ks) are a family of lipid kinases that propagate signaling cascades to regulate a wide range of cellular processes, such as proliferation and apoptosis ${ }^{8}$. PI3K phosphorylates the $3^{\prime}-\mathrm{OH}$ group of phosphatidylinositols at the plasma membrane, leading to the recruitment of the protein Ser/Thr-kinase, AKT, to the cell membrane, thus activating AKT. The 
PI3K/AKT signaling cascade is demonstrated to play a crucial role in carcinogenesis as it promotes cell survival and growth ${ }^{9,10}$. PI3K-AKT signaling is activated in cancer by several different mechanisms.

In recent years, a growing body of literature points toward the importance of ROS in mediating cell proliferation. They act as second messengers to modulate the activation of several signaling pathways ${ }^{11}$. A number of reports showed that the $\mathrm{PI} 3 \mathrm{~K} /$ Akt cascade is activated by $\mathrm{ROS}^{12}$. PI3K/AKT and MEK/ERK pathways play a vital role in regulating multiple cellular functions. Consequently, in this chapter, we will use AKT inhibitor LY294002 and ERK1/2 inhibitor U0126 to specifically test the involvement of MEK/ERK and PI3K/AKT pathways in ROS production via nano-scale particles or high concentration of fine particles. 


\section{MATERIALS AND METHODS}

\section{Reagents}

The antibodies against ERK, phospho-ERK(Thr202/Tyr204)/phospho-p44/p42 MAPK(Thr202/Tyr204), phospho-AKT (Ser473), AKT and ERK2 were from Cell Signaling Technology (Beverly, MA)

\section{Western blotting}

The cells were lysed in Radio Immuno Precipitation Assay(RIPA) buffer [150 $\mathrm{mM} \mathrm{NaCl}, 100 \mathrm{mM}$ Tris (pH 8.0), 1\% Triton X-100, 1\% deoxycholic acid, 0.1\% SDS, $5 \mathrm{mM}$ EDTA, and $10 \mathrm{mM} \mathrm{NaF}$, supplemented with Dithiothreitol(DTT) and proteinase inhibitors. The cellular lysates were clarified by centrifugation at $15,000 \times \mathrm{g}$ for $10 \mathrm{~min}$. Protein concentrations were determined by the Bradford assay (Bio-Rad). Aliquots of the protein extracts were resolved in SDS/polyacrylamide gels and transferred to nitrocellulose membranes. Membranes were blocked with $5 \%$ nonfat dry milk in 1x PBS buffer containing $0.05 \%$ Tween 20 , and incubated with primary antibodies against phospho-AKT, AKT, phospho-ERK1/2 (Cell Signaling Technology, Beverly, MA), and ERK2 (Santa Cruz Biotechnology, Santa Cruz, CA). Bands were detected by incubating the membrane with horseradish peroxidase-conjugated secondary antibodies and visualized with a chemiluminescence reagent (Pierce Biotechnology, Rockford, IL). Then indicated membranes were stripped in a stripping buffer $(50 \mathrm{mM}$ glycine, $100 \mathrm{mM} \mathrm{KCl}, 0.5 \mathrm{mM}$ EDTA, 
2-mercoptomethanol, 7M guandine hydrochloride) for $15 \mathrm{~min}$ at room temperature and washed three times with wash buffer for 15 min each time before reusing. 


\section{RESULTS}

WC-Co nanoparticles induced AKT and ERK1/2 activation

BEAS-2B cells were cultured in serum-free medium overnight, then treated with nano-size WC-Co particles at different doses for $30 \mathrm{~min}$. We found that low doses of WC-Co nanoparticles from 2.5 to $20 \mu \mathrm{g} / \mathrm{cm} 2$ resulted in an increasing of phosphoAKT and phosphoERK1/2, indicating activation (Fig. 1 and 2). In contrast, the expression of total AKT and ERK1/2 did not change.

WC-Co nanoparticles activated AKT and ERK pathways through ROS generation

To test whether ROS may be the upstream regulator of AKT and ERK, the cells were treated as above and analyzed for the activation of AKT and ERK by immunoblotting. The treatment with catalase inhibited levels of both phospho-AKT and phospho-ERK in the cells (Fig. 3). As a control, LY294002 and U0126 decreased WC-Co nanoparticle-inducing AKT and ERK activation, respectively. These results indicate that WC-Co nanoparticles regulate AKT and ERK pathways through ROS production.

High concentrations of WC-Co fine particles also induced AKT and ERK1/2 activation

To study whether high concentrations of the fine particles induced AKT and ERK1/2 activation, BEAS-2B cells were cultured in serum-free medium overnight, followed by treatment with $28.5,57$, and $85.5 \mu \mathrm{g} / \mathrm{cm} 2$ fine-size WC-Co particles for 
$30 \mathrm{~min}$. The cells were used to analyze AKT and ERK1/2 activation by immunoblotting. The increasing concentrations of WC-Co fine particles were associated with higher levels of AKT activation (Fig. 4.A). Similarly, 57 and 85.5 $\mu \mathrm{g} / \mathrm{cm} 2$ fine-size WC-Co particles induced ERK1/2 activation in the cells (Fig. 4.B). The levels of AKT and ERK1/2 activation induced by $85.5 \mu \mathrm{g} / \mathrm{cm} 2$ fine-size WC-Co particles were not as high as those treated with $5 \mu \mathrm{g} / \mathrm{cm} 2$ WC-Co nanoparticles, suggesting that 1) the WC-Co fine-size particles at high concentrations are able to induce AKT and ERK1/2 activation; and 2) the nanoparticles are more potent in inducing AKT and ERK1/2 activation in the cells. 
Figures and Legends

Fig.1. Effects of nanoparticles on phospho-AKT expression in vitro

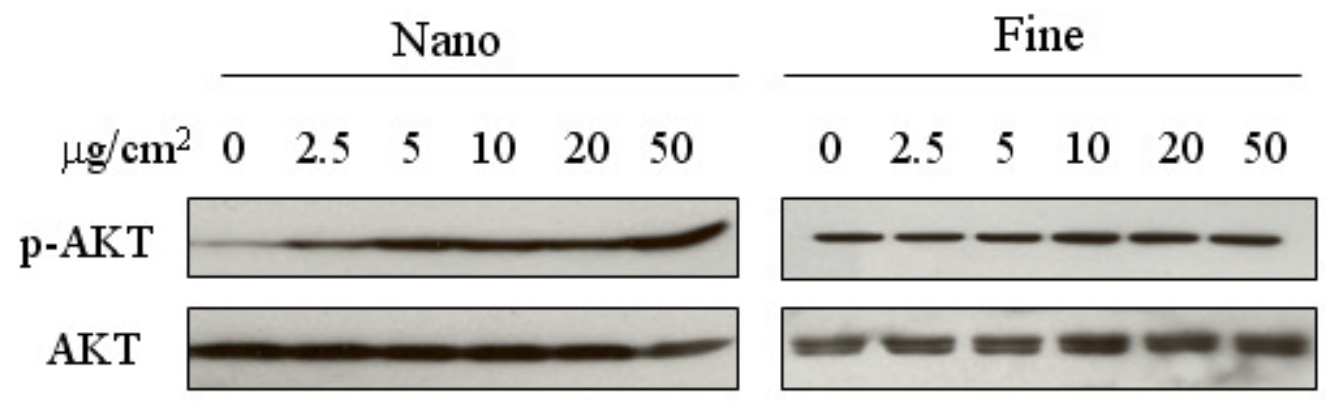

Fig.1. Effects of nanoparticles on phospho-AKT expression in vitro. Beas-2B cells were cultured in serum-free medium for $20 \mathrm{~h}$, then treated with nano-size and fine-size WC-Co particles at different concentrations $(0,2.5,5,10,20$, and $50 \mu \mathrm{g} / \mathrm{cm} 2)$ for $30 \mathrm{~min}$. The cells were collected, and total proteins were subjected to immunoblotting analysis with antibodies against $\mathrm{p}-\mathrm{AKT}$ and total AKT.

Fig.2. Effects of nanoparticles on phospho-ERK1/2 (ERK) expression in vitro

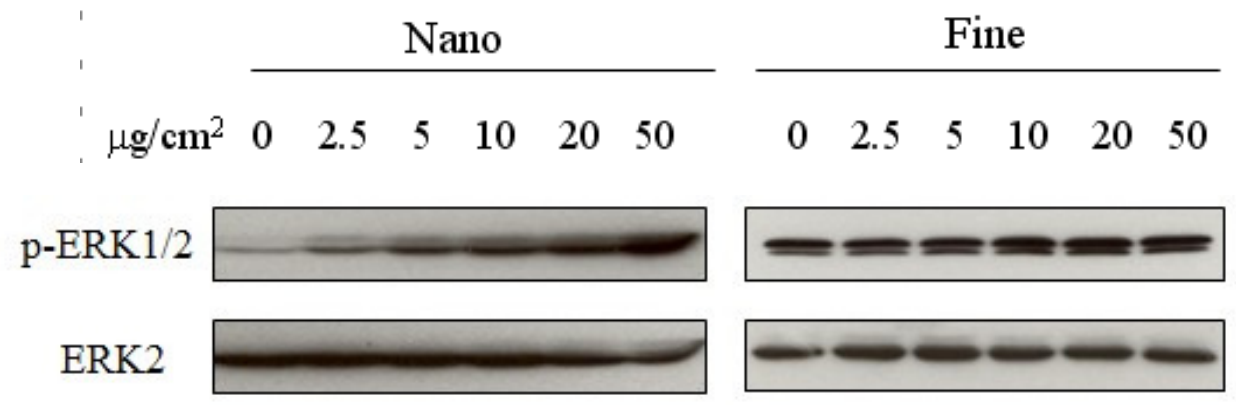

Fig.2. Effects of nanoparticles on phospho-ERK1/2 (ERK) expression in vitro. Beas-2B cells were cultured in serum-free medium for $20 \mathrm{~h}$, then treated with nano-size or fine sized WC-Co particles at different concentrations $(0,2.5,5,10,20$, and $50 \mu \mathrm{g} / \mathrm{cm} 2)$ for $30 \mathrm{~min}$. Then cells were collected, and the total proteins were subjected to immunoblotting analysis with antibodies against $\mathrm{p}$-ERK1/2 and total ERK1/2.

Fig.3. effect of catalase, LY294002 and U0126 and nanoparticles on AKT and ERK1/2 (ERK) activation. 


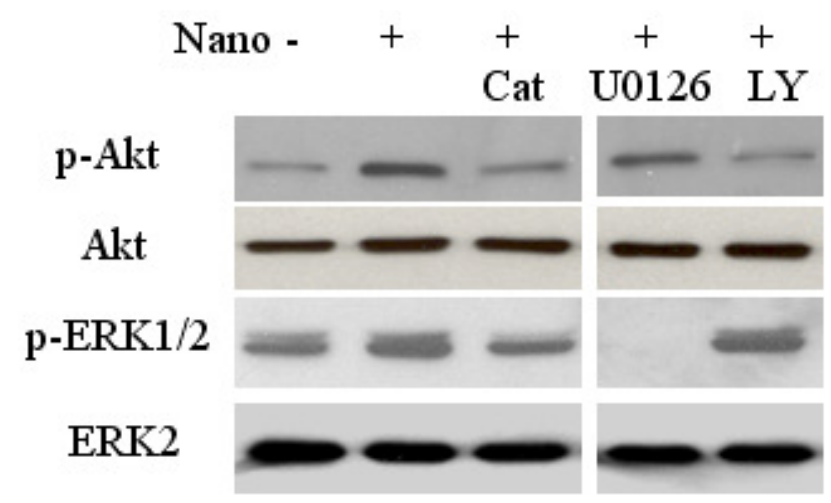

Fig.3. effect of catalase, LY294002, U0126 and nanoparticles on AKT and ERK1/2 activation. BEAS-2B cells were cultured to $80 \%$ confluence, then treated with $3000 \mathrm{U} / \mathrm{ml}$ of catalase, 20 $\mu \mathrm{M}$ U0126, or $20 \mu \mathrm{M}$ LY294002 for $30 \mathrm{~min}$ in fresh medium. Then nano-size of WC-Co at 5 $\mu \mathrm{g} / \mathrm{cm} 2$ was added for $1 \mathrm{~h}$. Cell lysates were subjected to Western Blotting

Fig.4. Effects of high concentration WC-Co fine particles on AKT and ERK1/2 activation.

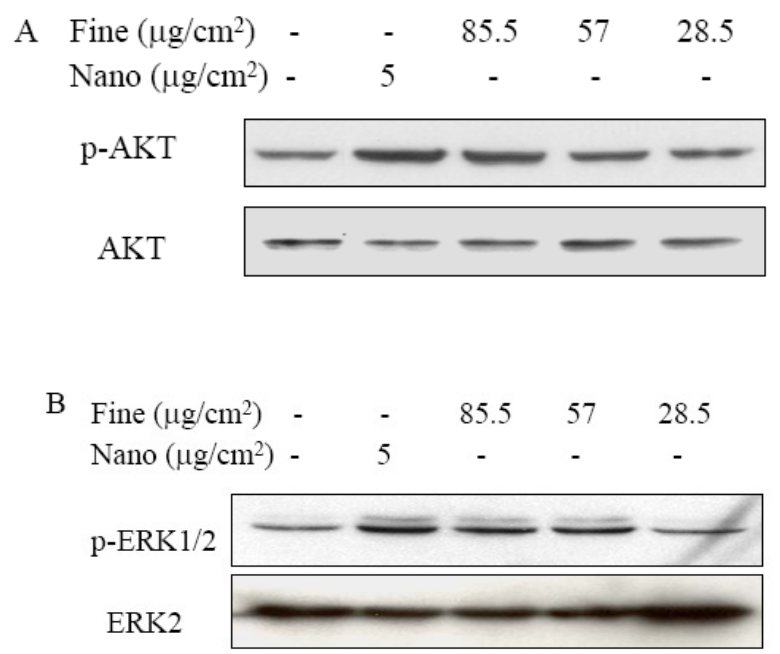

Fig.4. Effects of high concentration WC-Co fine particles on AKT and ERK1/2 (ERK) activation. Beas-2B cells were cultured in serum-free medium for $20 \mathrm{~h}$, then treated with nano-size or fine-size of WC-Co particles at the indicated concentrations for $30 \mathrm{~min}$. Cells were lysed and the total proteins were subjected to immunoblotting analysis with antibodies against $\mathrm{p}-\mathrm{AKT}$ and total AKT (A) or $\mathrm{p}-\mathrm{ERK} 1 / 2$ and total ERK1/2 (B). 


\section{DISCUSSION}

We found in the preliminary studies that WC-Co nanoparticles induced ROS production in both BEAS-2B and JB6 cells. ROS generation induced by WC-Co nanoparticles was inhibited by catalase and DPI, indicating that NADPH oxidase could be source of ROS. U0126 and LY294002, the inhibitors of PI3K/AKT and MEK pathways, did not inhibit ROS production, suggesting that ROS production did not require activation of $\mathrm{AKT}$ and ERK. However, WC-Co nanoparticles might affect downstream phospho-AKT, phospho-ERK expression. Indeed, our data suggested that WC-Co nanoparticles increased the activation of AKT and ERK1/2 signaling pathways in BEAS-2B cells compared to the same concentration of fine sized particles, indicating that PI3K/AKT and MEK/ERK pathways may play important roles in WC-Co nanoparticle-mediated functional changes in the cells. Because AKT and ERK1/2 signaling pathways were not involved in ROS production, we hypothesized that these two pathways may still be activated downstream of ROS. In agreement with our predictions, ROS blockade with catalase greatly reduced the activation of ERK and AKT.

It is noteworthy that PI3K/AKT and MEK/ERK pathways are thought to be synergistically regulated and crosstalk between them has been reported in some cancer cell lines ${ }^{13,14}$. However, in our study, MEK inhibitor U0126 only blocked the activation of ERK but had no effect on phospho-AKT, and PI3K inhibitor LY294002 only inhibits the phosphorylation of AKT but not the phosphorylation of ERK. This 
suggests that these two pathways are distinct from each other in mediating nanoparticle signaling.

High concentration of fine sized particles induced ROS generation in this study. Moreover, we also found that high concentration of the fine-sized particles induced AKT and ERK1/2 activation. Notably, the level of activation is lower than for the same area size of nanoparticles, suggesting that: 1) nanoparticles are more potent in activating AKT and ERK1/2 pathways in BEAS-2B cells which is consistent with their effect on ROS generation, 2) WC-Co as a heavy metal compound induces AKT and ERK activation regardless of the physical particle size. 
Reference List

1. Haagenson KK, Wu GS. Mitogen activated protein kinase phosphatases and cancer. Cancer Biol Ther.,9:337-340,2010.

2. Keshet Y, Seger R.The MAP kinase signaling cascades: a system of hundreds of components regulates a diverse array of physiological functions. Methods Mol Biol., 661:3-38,2010.

3. Whyte J, Bergin O, Bianchi A, McNally S, Martin F. Key signalling nodes in mammary gland development and cancer. Mitogen-activated protein kinase signalling in experimental models of breast cancer progression and in mammary gland development. Breast Cancer Res., 11:209,2009.

4. Raman et al., 2007 M. Raman, W. Chen and M.H. Cobb, Differential regulation and properties of MAPKs. Oncogene, 26:3100-3112, 2007.

5. Roberts PJ, Der CJ. Targeting the Raf-MEK-ERK mitogen-activated protein kinase cascade for the treatment of cancer. Oncogene., 26:3291-3310,2007.

6. McCubrey JA, Steelman LS, Chappell WH, Abrams SL, Wong EW, Chang F, Lehmann B, Terrian DM, Milella M, Tafuri A, Stivala F, Libra M, Basecke J, Evangelisti C, Martelli AM, Franklin RA. Roles of the Raf/MEK/ERK pathway in cell growth, malignant transformation and drug resistance. Biochim Biophys 
Acta., $\quad$ 1773:1263-1284, 2007.

7. Torres M, Forman HJ.Redox signaling and the MAP kinase pathways. Biofactors, 17:287-296,2003.

8. J.A. Engelman. Targeting PI3K signalling in cancer: opportunities, challenges and limitations. Nat Rev Cancer, 9:550-562,2009.

9. J.A. Engelman, J. Luo and L.C. Cantley. The evolution of phosphatidylinositol 3-kinases as regulators of growth and metabolism. Nat Rev Genet., 7:606-619, 2006.

10. I. Vivanco and C.L. Sawyers. The phosphatidylinositol 3-kinase AKT pathway in human cancer. Nat Rev Cancer., 2:489-501, 2002.

11. Barthel A, Ostrakhovitch EA, Walter PL, Kampkötter A, Klotz LO. Stimulation of phosphoinositide 3-kinase/Akt signaling by copper and zinc ions: mechanisms and consequences. Arch Biochem Biophys., 463:175-182, 2007.

12. Chartoumpekis D, Ziros PG, Psyrogiannis A, Kyriazopoulou V, Papavassiliou AG, Habeos IG. Simvastatin lowers reactive oxygen species level by Nrf2 activation via PI3K/Akt pathway. Biochem Biophys Res Commun., 
396:463-466,2010.

13. $\mathrm{Xu} \mathrm{J}$, Messina JL.Crosstalk between growth hormone and insulin signaling. Vitam Horm.,80:125-153,2009.

14. Rongyang Dai, Run Chen, Hong Li. Cross-talk between PI3K/Akt and MEK/ERK pathways mediates endoplasmic reticulum stress-induced cell cycle progression and cell death in human hepatocellular carcinoma cells. Int J Oncol.,34:1749-1757,2009. 


\section{CHAPTER IV}

WC-Co nanoparticles induced AP-1, NF- $\mathrm{KB}$, and VEGF

transcriptional activation and angiogenesis 


\begin{abstract}
AP-1, NF- $\kappa$ B, and VEGF are conventionally known to be involved in regulating angiogenesis ${ }^{1,2,3}$. This prompted us to hypothesize that elevated levels of ROS caused by WC-Co nanoparticle treatment might also upregulate AP-1, NF- $\mathrm{KB}$, and VEGF transcriptional activation. Indeed, BEAS-2B cells treated with 2.5 and $5 \mu \mathrm{g} / \mathrm{cm} 2$ of nano-sized WC-CO showed significantly increased AP-1, NF- $\mathrm{BB}$, and VEGF transcriptional activation, while fine-sized WC-CO had no effect. Our results show that nanoparticle treatment results in AP-1, NF- $\mathrm{BB}$, and VEGF transcriptional activation.
\end{abstract}

Angiogenesis is an essential process during injury repair, inflammatory diseases, carcinogenesis, tumor growth and metastasis ${ }^{4,5}$. To test the effect of WC-Co nanoparticles in angiogenesis, we used chick chorioallantoic membrane (CAM ) assay as the in vivo angiogenesis model. Our results suggest that the nanoparticle treatment increased the angiogenic response by more than 5 fold when compared to the control group. To further demonstrate the effect of the nanoparticles on angiogenesis on a different cell line, human lung adenocarcinoma cells A549 were used. We found that treatment of A549 cells with nanoparticles enhanced the angiogenic response by 5 -fold. These data demonstrate that the WC-Co nanoparticles can significantly stimulate different cell lines to induce angiogenesis in vivo. We also tested the effects of fine size particles on angiogenesis and found that the fine size particles at the same dose did not induce angiogenesis (data not shown). 


\section{INTRODUCTION}

Angiogenesis occurs via the sprouting of new vessels from preexisting blood vessels or via the insertion of interstitial tissue columns into the lumen of pre-existing vessels (i.e., intussusception) ${ }^{6}$. Tumors cannot grow larger than 1-2 millimeters in diameter without an efficient blood supply provided by angiogenesis ${ }^{7}$. Tumor angiogenesis can be triggered by extracellular signals, such as growth factors, and by genetic alterations, such as activation of oncogenes or deletion of tumor suppressor genes. It is a complex process regulated by a balance of angiogenic inducers such as VEGF and angiogenic inhibitors such as thrombospondin- $1^{8}$.

Nuclear factor kappaB (NF-kB), member of the proto-oncogene family rel, is an ubiquitous transcription factor. The activated form of NF-kB consists of heterodimer $\mathrm{p} 50 / \mathrm{p} 65$, it cooperates with other transcription factors to bind to a specific DNA sequence, thus induces the expression of various target genes to promote cell proliferation and transformation, regulates apoptosis, stimulates invasion and metastasis as well as facilitates angiogenesis ${ }^{9,10}$. Activator protein-1 (AP-1) is a dimeric protein, which comprises members of the Jun protein family (c-Jun, JunB, and JunD) and Fos protein family, consisting either of homodimers between c-Jun, JunB, and JunD, or heterodimers with members of the Fos-family via the physical 1 interaction with "leucine zipper" region ${ }^{11}$. The protein components of AP1 are encoded by a set of genes known as "immediate-early" genes that can be activated by a variety of growth factors and mitogens through several different signaling 
pathways $^{12}$.

Chemical carcinogenesis is a multi-step process involving both mutations and deregulated cell proliferation. Oxidative stress can occur through overproduction of reactive oxygen species (ROS) or nitrogen species through either endogenous or exogenous insults. It has been pointed out by several recent studies that the unregulated or prolonged production of cellular oxidants is linked to mutations (induced by oxidant-induced DNA damage), as well as the modification of gene expression, which is proved to be important in carcinogenesis ${ }^{13,14}$. In particular, signal transduction pathways, including transcriptional factors AP-1 and NF- $\mathrm{BB}$, are known to be activated by reactive oxygen species, leading to the transcription of genes involved in cell growth regulatory pathways ${ }^{15}$. There is already mounting evidence that demonstrates the association of ROS generation and carcinogenesis via the activation of several key transcription factors such as AP-1 and NF- $\mathrm{KB}^{16}$.

VEGF is the predominant stimulator of angiogenesis. VEGF secreted by tumor cells initiates the angiogenic process by activating endothelial cells and promoting their migration, thus, inducing the angiogenic switch ${ }^{17}$. VEGF expression is driven by many factors that are characteristic of tumors, including oncogene expression [e.g., ras, src, erbB2/human epidermal growth factor receptor 2 (HER2), EGFR] and hypoxia $]^{18}$. VEGF also mediates the effects of other angiogenic molecules and therefore plays a central role in the control of tumor angiogenesis ${ }^{19}$. Under hypoxic conditions, constitutive degradation of HIF-1 $\alpha$ via the proteosome pathway is blocked leading to HIF-1 stabilization and activation. HIF-1 is also stabilized through 
oncogenic signaling, involving src, ras, protein kinase $\mathrm{C}$, and phosphatidylinositol-3-OH kinase $(\mathrm{PI} 3 \mathrm{~K})^{20}$. In the nucleus, HIF-1 binds the VEGF promoter region and activates transcription of the VEGF gene ${ }^{21}$.

A number of studies showed that the toxic effect of nanoparticles involves its effect on angiogenesis, however, the underlying mechanisms remain unclear ${ }^{22,23}$. Based on the vital role played by AP-1, NF- $\mathrm{KB}$ and VEGF in angiogenesis, as well as their tight relationship with ROS, it is tempting to speculate that AP- $1, \mathrm{NF}-\kappa \mathrm{B}$, and VEGF transcriptional activation may be involved in the nanoparticle induced angiogenesis. Only few studies have focused on in vivo models. Therefore, in this chapter we want to investigate the effect of nanoparticles on AP-1, NF- $\mathrm{BB}$, and VEGF transcriptional activation, and to further determine the effect of angiogenesis in vivo using the CAM model. 


\section{MATERIALS AND METHODS}

\section{Transient transfection and luciferase assay}

BEAS-2B cells were seeded in 12 -well plates and cultured to $70 \%$ confluence. The cells were transiently transfected with AP-1, NF- $\mathrm{KB}$, or VEGF reporter plasmids and pCMV- $\beta$-galactosidase ( $\beta$-gal) using Lipofectamine (Invitrogen, Carlsbad, CA) according to the manufacturer's instructions. After transfection, the cells were cultured overnight, followed by different treatments. Cells were washed in PBS and lysed with reporter lysis buffer (Promega, Madison, WI). The luciferase (Luc) activities of the cell extracts were determined using the luciferase assay system (Promega, Madison, WI). The relative luciferase activity (defined as VEGF reporter activity) was calculated as the ratio of Luc/ $\beta$-gal activity, and normalized to the control.

\section{Chicken Chorioallantoic Membrane (CAM) angiogenesis assay}

White Leghorn chicken eggs were fertilized and incubated at $37^{\circ} \mathrm{C}$ with $70 \%$ humidity for 9 days. An artificial air sac was created over a region containing small blood vessels in the chicken chorioallantoic membrane (CAM) as described previously (Jiang et al., 2000). To test angiogenesis, the BEAS-2B cells or A549 cells were trypsinized, washed, and resuspended at $10 \times 107$ cells $/ \mathrm{ml}$ in serum-free medium containing 50\% Matrigel (BD Biosciences, Bedford, MA). Aliquots $(3 \times 106$ cells, $30 \mu \mathrm{l}$ ) of the mixture or the matrigel alone were then applied onto the CAM of 9-day-old embryos. The area around the implanted Matrigel was photographed 
using a Nikon digital camera 4 days after the implantation, and the number of blood vessels was determined by counting the branching points of blood vessels in a unit area on the CAM. The experiments were performed using 10 chicken embryos for each treatment. Data were expressed as the mean $\pm \mathrm{SD}$ from replicate experiments.

\section{Statistical Analysis}

The data were analyzed using SPSS statistics software package (SPSS, Chicago, IL). All of the results are expressed as mean \pm SD from three independent experiments, unless otherwise indicated, and the difference at $\mathrm{p}<0.05$ was considered significant. 


\section{RESULTS}

Low doses of WC-Co nanoparticles induced AP-1, NF- $K B$, and VEGF transcriptional activation

BEAS-2B cells were co-transfected with AP-1, NF- $\kappa B$, and VEGF reporter with $\beta$-gal plasmid, then treated with nano- or fine-size of WC-Co particles (WC/CO). As shown in Fig. 1, doses of 2.5 and $5 \mu \mathrm{g} / \mathrm{cm} 2$ nano-size $\mathrm{WC} / \mathrm{CO}$ significantly induced AP-1, NF- $\mathrm{KB}$, and VEGF transcriptional activation, while fine-size $\mathrm{WC} / \mathrm{CO}$ had no effect. These results shows that the nanoparticles induce AP-1, NF- $\mathrm{BB}$, and VEGF transcriptional activation.

The treatment of Beas-2B and A549 cells with low doses of WC-Co nanoparticles induced angiogenesis

In order to test the physiological function of WC-Co nanoparticles, Beas-2B cells were treated with the nanoparticles at $5 \mu \mathrm{g} / \mathrm{cm} 2$ for $24 \mathrm{~h}$, or left untreated (control); cells were trypsinized, mixed with Matrigel, and used for angiogenesis assay in the CAM. Beas-2B cells alone did not show an increase in angiogenesis, however, the nanoparticle treatment greatly induced angiogenesis (Fig. 2A). The relative angiogenesis responses were analyzed by the number of microvessel branches in the unit area. The nanoparticle treatment increased angiogenesis more than 5-fold compared to the control group (Fig. 2B). To further test the effect of the nanoparticles in a different cell line, A549 cells were treated as above to analyze the angiogenesis response. Although A549 cells induced angiogenesis, treatment with 
nanoparticles greatly enhanced angiogenesis-nearly 5-fold induction of angiogenesis response was observed compared to that of A549 cells alone (Fig. 2C and D). These data indicate that nanoparticles stimulate different cells to induce angiogenesis. We also tested the effects of fine-sized particles in angiogenesis, and found that fine particles did not induce angiogenesis (data not shown). 
Figures and Legends

Fig.1. WC-Co nanoparticles induced AP-1, NF- $\mathrm{KB}$, and VEGF transcriptional activation in Beas-2B cells.
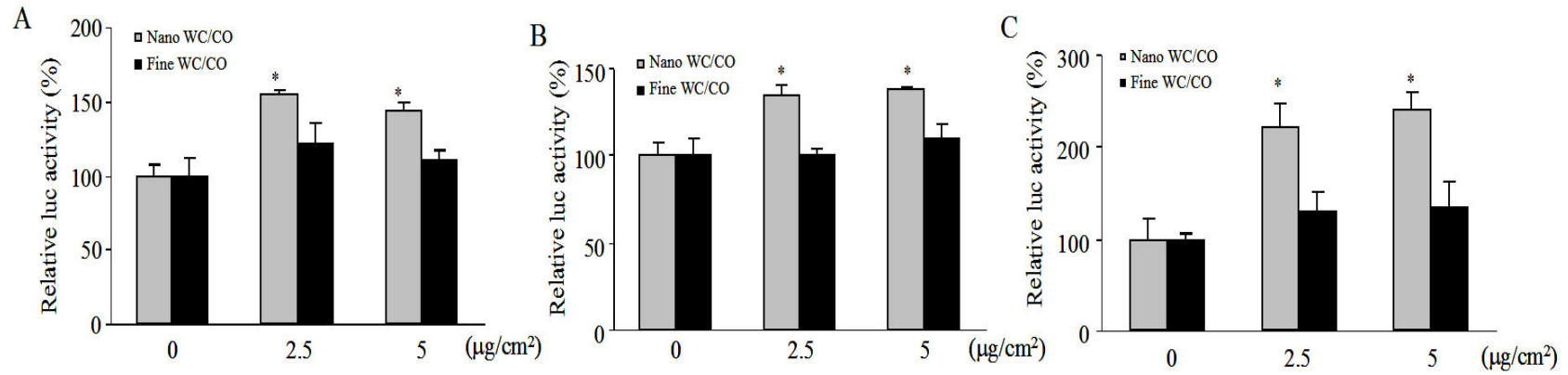

Fig.1. WC-Co nanoparticles induced AP-1, NF- $\mathrm{KB}$, and VEGF transcriptional activation in Beas-2B cells. (A) Beas-2B cells were co-transfected with AP-1 luciferase reporter plasmid $(0.4 \mu \mathrm{g})$ and $\beta$-gal plasmid $(0.2 \mu \mathrm{g})$. After transfection, the cells were cultured overnight in fresh medium, then treated with nano- or fine-size WC-Co particles (WC/CO) $(0,2.5$ and 5 $\mu \mathrm{g} / \mathrm{cm}^{2}$ ) for $24 \mathrm{~h}$. The cells were then lysed and the supernatants were subjected to luc and $\beta$-gal activity assay. Relative luciferase activity was determined by the ratio of luc to $\beta$-gal activity, and normalized to that of the control. (B) Cells were co-transfected with NF-KB. reporter plasmid $(0.4 \mu \mathrm{g})$ and $\beta$-gal plasmid $(0.2 \mu \mathrm{g})$, treated as above to analyze relative luciferase activity. (C) Cells were co-transfected with human VEGF reporter plasmid $(0.4 \mu \mathrm{g})$ and $\beta$-gal plasmid $(0.2 \mu \mathrm{g})$, treated as above to analyze relative luciferase activity. indicates that the value was significantly different when compared to that of the control $(P<0.05)$.

Fig.2. Beas-2B or A549 cells treated with WC-Co nanoparticles significantly induced angiogenesis.

A

$$
\text { CAM }
$$

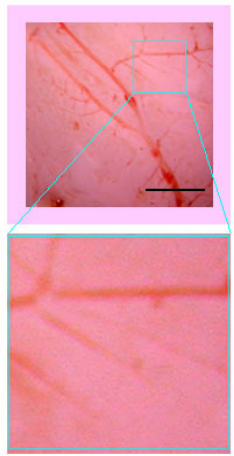

Beas2B

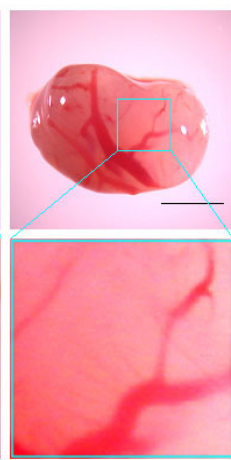

Beas2B-nano WC/CO

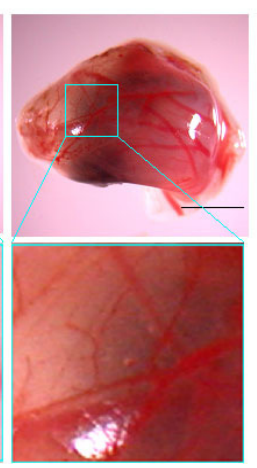

B

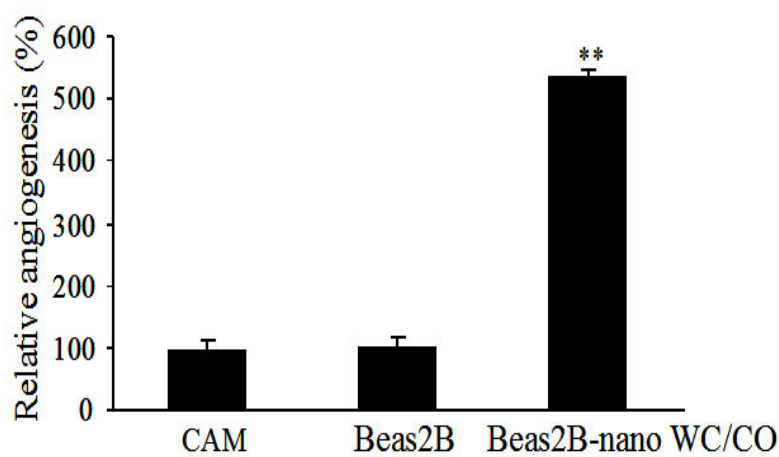


$\mathbf{C}$

CAM

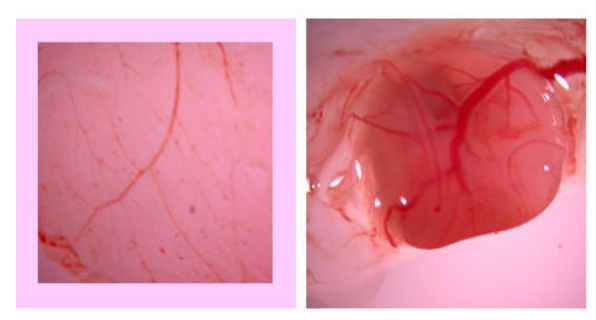

A549-nano WC/CO

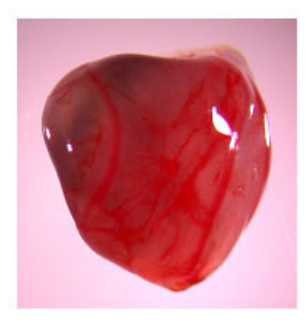

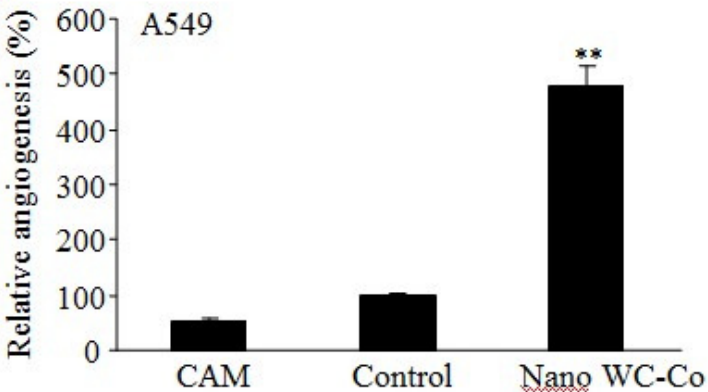

Fig.2. Beas-2B or A549 cells treated with WC-Co nanoparticles significantly induced angiogenesis. (A) Beas-2B cells were treated without or with $5 \mu \mathrm{g} / \mathrm{cm}^{2}$ of WC-Co nanoparticles for $24 \mathrm{~h}$, then trypsinized, resuspended in serum-free medium $\left(3 \times 10^{7} \mathrm{cells} / \mathrm{ml}\right.$, $0.1 \mathrm{ml}$ ), and mixed in 1:1 ratio with Matrigel (Collaborative Biomedical Products, Bedford, MA). Aliquots of the mixture were then applied to the CAM of 9-day-old embryos. After $96 \mathrm{~h}$ incubation, the area around the implanted Matrigel was photographed with a Nikon digital camera, and the numbers of blood vessel branching were counted. Assays for each treatment were carried out using 10 embryos per experiment. Representative photos were obtained from the CAM alone, the CAM with Beas-2B cells treated without or with WC-Co nanoparticles (upper panel), and magnified unit area of up panel (lower panel). Bar: $2 \mathrm{~mm}$. (B) The number of blood vessels was obtained by counting the branching of blood vessels, and the relative angiogenesis was obtained by normalizing to that of the CAM control. The data represent the mean $\pm S E$ of the relative angiogenesis from 8 different embryos. ${ }^{* *}$ indicates that the value was significantly different when compared to that of the control $(P<0.01)$. (C) A549 cells were treated and used for the angiogenesis assay as described above for Beas-2B cells. Representative photos generated from the CAM alone, or A549 cells treated without or with WC-Co nanoparticles. (D) Relative angiogenesis was analyzed as above, and normalized to that of A549 cells alone. The mean $\pm S E$ of the relative angiogenesis was from 8 different embryos. ${ }^{* *}$ indicates that the value was significantly different when compared to that of $A 549$ cells $(P<0.01)$. 


\section{DISCUSSION}

Transcription factors serve as integration points of the different signaling cascades that control the expression of a specific gene. The regulation of these transcription factors themselves is therefore of critical importance in determining the response to various physiological and environmental stimuli. To study the transcriptional activities of AP-1, NF- $\mathrm{BB}$, and VEGF in WC-Co particles-treated cells, cells were treated with the same concentration of nano-sized or fine-sized particles, results showed that nanoparticles obviously induce the activity of the three transcriptional factors compared to fine-sized particles, although, we can also see subtle increase in activities of fine-sized particles, which may indicate that heavy metals can upregulate transcriptional activities of AP-1, NF- $\mathrm{BB}$, and VEGF regardless of powder size. VEGF shows the biggest activation difference between fine-sized and nano-sized particles when compared to AP-1 and NF- $\mathrm{BB}$, insofar. VEGF is among the most powerful angiogenic cytokines in many cancers ${ }^{24}$, thus, we hypothesized that VEGF is also the most important factor in WC-Co nanoparticle- induced tumor growth and angiogenesis compared to AP-1 and NF- $\mathrm{\kappa B}$.

Angiogenesis assay in chicken embryo (CAM) was used as in vivo assay to study the effects of WC-Co nanoparticle. CAM assay possesses several advantages, among the most valuable features, it is relatively easy to carry out and less expensive than other in vivo angiogenesis assays, however, some articles pointed out that the CAM itself already contains a well-developed vascular network, during the course of embryonic development. CAM undergoes gradual change in endothelial cell 
proliferation, which makes it difficult to discriminate between newly formed capillaries and the already existing ones ${ }^{25,26}$. In order to reduce the unrelated factors that would influence our results, we perform ten replicates for each treatment. The results show that nanoparticle-treated cells are more efficient in inducing angiogenesis in vivo in xenografts from both A549 cell line and BEAS-2B cell line (with almost the same activation pattern). This suggests that WC-Co nanoparticle-treated lung epithelial cells have significantly increased capacity to induce angiogenesis in vivo. 


\section{Reference List}

1. Jeffrey M. Isner. VEGF-induction of angiogenesis. Journal of Vascular Surgery,31:1252-1255,2000.

2. Nikhlesh K. Singh,Dong Van Quyen,Venkatesh Kundumani-Sridharan,

Peter C. Brooks, Gadiparthi N. Rao. AP-1 (Fra-1/c-Jun)-mediated Induction of Expression of Matrix Metalloproteinase-2 Is Required for 15(S)-Hydroxyeicosatetraenoic Acid-induced Angiogenesis. The Journal of Biological Chemistry, 285:16830-16843,2010.

3. Jiali Zhang, Bin Peng. In vitro angiogenesis and expression of nuclear factor NF- $\mathrm{KB}$ and VEGF in high and low metastasis cell line of salivary gland Adenoid Cystic Carcinoma. BMC cancer, 7:95, 2007.

4. Sharma, R. A., Harris, A. L., Dalgleish, A. G., Steward, W. P., and O'Byrne, K. J. Angiogenesis as a biomarker and target in cancer chemoprevention. Lancet Oncol., 2: 726-732, 2001.

5. Folkman,J, Tumor angiogenesis. Adv. Cancer Res., 19: 331-358,1974.

6. Folkman,J, Angiogenesis in cancer, vascular, rheumatoid and other disease.Nat. Med. 1: 27-31.1995 
7. Claffey, K. P., Brown, L. F., del Aguila, L. F., Tognazzi, K., Yeo, K. T., Manseau, E. J., and Dvorak, H. F. Expression of vascular permeability factor/vascular endothelial growth factor by melanoma cells increases tumor growth, angiogenesis, and experimental metastasis. Cancer Res., 56: 172-181, 1996.

8. Plate, K. H., Breier, G., Millauer, B., Ullrich, A., and Risau, W. Up-regulation of vascular endothelial growth factor and its cognate receptors in a rat glioma model of tumor angiogenesis. Cancer Res., 53: 5822-5827, 1993.

9. Giuliani C, Napolitano G, Bucci I, Montani V, Monaco F. Nf-kB transcription factor: role in the pathogenesis of inflammatory, autoimmune, and neoplastic diseases and therapy implications. Clin Ter. ,152:249-253,2001.

10. Karin M. Nuclear factor-kappaB in cancer development and progression. Nature,441:431-436,2006.

11. Virna D Leaner $\underline{1}$, Ichiro Kinoshita1 and Michael J Birrer. AP-1 complexes containing cJun and JunB cause cellular transformation of Rat1a fibroblasts and share transcriptional targets. Oncogene, 22: 5619-5629,2003.

12. Vesely PW, Staber PB, Hoefler G, Kenner L. Translational regulation 
mechanisms of AP-1 proteins. Mutat Res., 682:7-12,2009.

13. Klaunig JE, Kamendulis LM. The role of oxidative stress in carcinogenesis. Annu Rev Pharmacol Toxicol, 44:239-67,2004.

14. Klaunig JE, Kamendulis LM, Hocevar BA.Oxidative stress and oxidative damage in carcinogenesis. Toxicol Pathol,38:96-109, 2010.

15. Haiying Fan, Baogui Sun, Qiuping Gu, Anne Lafond-Walker, Suyi Cao, and Lewis C. Becker. Oxygen radicals trigger activation of NF- $\kappa \mathrm{B}$ and AP-1 and upregulation of ICAM-1 in reperfused canine heart. Am J Physiol Heart Circ Physiol., 282: 1778-1786, 2002.

16. Dhar A, Young MR, Colburn NH. The role of AP-1, NF-kappaB and ROS/NOS in skin carcinogenesis: the JB6 model is predictive. Mol Cell Biochem.23:185-193,2002.

17. Bruce I. Terman and Konstantin V. Stoletov. VEGF and Tumor Angiogenesis Einstein Quart. J. Biol. and Med. 18:59-66,2001.

18. Tammela T, Enholm B, Alitalo K, Paavonen K. The biology of vascular endothelial growth factors. Cardiovasc Res., 65:550-63,2005. 
19. H.M. Pinedoa, Dennis J. Slamonb. Translational Research: The Role of VEGF in Tumor Angiogenesis. The Oncologist Suppl., 1:1-2,2000.

20. Jennifer E. Ziello,ab Ion S. Jovin,a and Yan Huanga. Hypoxia-Inducible Factor (HIF)-1 Regulatory Pathway and its Potential for Therapeutic Intervention in Malignancy and Ischemia. Yale J Biol Med., 80: 51-60,2007.

21. Westra J, Molema G, Kallenberg CG. Hypoxia-inducible factor-1 as regulator of angiogenesis in rheumatoid arthritis - therapeutic implications. Curr Med Chem., $17: 254-263,2010$.

22. Min Ding1, Jinshun Zhao1, Linda Bowman1, Vince Castranova1 and Bing-Hua Jiang2Tungsten Carbide-cobalt Nanoparticles Induce Reactive Oxygen Species, AKT, ERK, AP-1, NF-кB, VEGF, and Angiogenesis, The FASEB Journal, 228:33-37,2010.

23. Kemp MM, Kumar A, Mousa S, Dyskin E, Yalcin M, Ajayan P, Linhardt RJ, Mousa SA.Gold and silver nanoparticles conjugated with heparin derivative possess anti-angiogenesis properties. Nanotechnology. Epub., 20:45-51, 2009. 
24. Ferrara N. Role of vascular endothelial growth factor in physiologic and pathologic angiogenesis: therapeutic implications. Semin Oncol.,29:10-14,2002.

25. Staton CA, Reed MW, Brown NJ.A critical analysis of current in vitro and in vivo angiogenesis assays. Int J Exp Pathol. 90:195-221,2009.

26. Ribatti D,Rom J Morphol. Embryol, The chick embryo chorioallantoic membrane in the study of tumor angiogenesis. 49:131-135,2008. 


\section{CHAPTER V}

DISCUSSION AND CONCLUSION 


\section{Discussion}

WC-Co nanoparticles

Despite the extensive studies on WC-Co toxicity, there is still much left to be explored regarding its mechanism of action as well as intracellular damage. With the nanotechnology industry growing exponentially over these few years, the evolution of nanotechnology brings yet another aspect of WC-Co-the biological toxicity of WC-Co nanoparticles. Because of the extremely small physical size of the nanoparticles, which is similar to many biological molecules and structures, like antibodies, proteins, viruses, etc. they can easily enter cells, organelles, tissues and interact with functional biomolecular structures (e.g. DNA, RNA) ${ }^{1}$. There is a common assumption that the nanoscale materials act via quite different mechanisms and reactions compared to their fine sized counterparts. Recent evidence has indicated that nanoparticles exhibit a higher deposition in all regions of the respiratory tract when compared to the fine particles ${ }^{2}$.

Nanoparticles and reactive oxygen species in the cells

Recent studies indicated that the adverse and toxic effects of inhaled nanoparticles may be associated with the oxidative stress by the increasing generation of reactive oxygen species (ROS) $)^{3,4,5}$. ROS include superoxide, hydrogen peroxide $\left(\mathrm{H}_{2} \mathrm{O}_{2}\right)$ and hydroxyl radical. Low levels of ROS are produced by all aerobic organisms through the oxygen reduction process. ROS are also induced by growth factors and cytokines and are important for cancer cell proliferation and tumor 
development. In fact, in recent years, ROS have been regarded as having carcinogenic potential and have been associated with tumor progression in various studies. ROS possess four properties that contribute to carcinogenesis: 1) they cause structural change in DNA by introducing base-pair mutation, deletion, insertion, rearrangement, and sequence amplification. 2) they initiate lipid peroxidation. 3) they activate cytoplasmic and nuclear signal transduction pathways. 4) they can modulate the activity of stress protein and stress genes so as to regulate growth, differentiation, and cell death. Cells have developed a variety of enzymatic and non-enzymatic mechanisms to defend themselves against damage resulting from oxidative stress including antioxidant defense such as glutathione and antioxidant enzymes. The most important antioxidant enzymes include the superoxide dismutases $\left(\mathrm{SOD}^{-1}\right.$ and $\left.\mathrm{SOD}^{-2}\right)$, which catalyze $\mathrm{O}_{2} \cdot-$ to $\mathrm{H}_{2} \mathrm{O}_{2}+\mathrm{H}_{2} \mathrm{O}$; catalase, which catalyzes $\mathrm{H}_{2} \mathrm{O}_{2}$ to $\mathrm{O}_{2}+\mathrm{H}_{2} \mathrm{O}$; and glutathione peroxidase which converts $\mathrm{H}_{2} \mathrm{O}_{2}$ to $\mathrm{H}_{2} \mathrm{O}$. Recent studies indicated that expression of NADPH oxidase may play an important role in ROS generation in some cancer cells $\mathrm{s}^{6,7,8}$.

PI3K, AKT, and ERK1/2 regulate VEGF and HIF-1 expression

Hypoxia-inducible factor 1 (HIF-1), is a heterodimeric transcription factor composed of two subunits: HIF- $1 \alpha$ and HIF-1 $\beta$. HIF- $1 \alpha$ is degraded during normoxia, whereas HIF-1 $\beta$ is constitutively expressed and stable under normoxic conditions. In contrast, HIF-1 $\alpha$ is rapidly ubiquitinated by the von Hippel-Lindau tumor suppressor E3 ligase complex and subjected to proteasomal degradation. During hypoxia, 
HIF-1 $\alpha$ proteosomal degradation is prevented through HIF-1 $\alpha$ protein modifications, leading to its accumulation and translocation to the nucleus to form an active heterodimer with HIF-1 $\beta^{9}$. It has been found that HIF- $1 \alpha$ protein synthesis can also be regulated by activation of the phosphatidylinositol 3-kinase (PI3K) and ERK mitogen-activated protein kinase (MAPK) pathway ${ }^{10}$. Various studies demonstrated that the expression of HIF-1 $\alpha$ is induced in human cells by hypoxia, growth factors, and oncogenes. HIF-1 $\alpha$ protein content is a rate-limiting factor for HIF-1 activity. HIF-1 regulates the expression of many genes, including VEGF, heme oxygenase 1, inducible nitric oxide synthase (iNOS), several glycolytic enzymes, p21 and others ${ }^{11}$. HIF-1 activation is important for tumorigenicity and angiogenesis in nude mice. HIF- $1 \alpha$ expression is frequently increased in many human cancers and in angiogenesis $^{12,13}$

It has been demonstrated that PI3K/AKT signaling pathway is required for HIF-1-mediated VEGF expression in response to growth factor stimulation and oncogene activation ${ }^{14}$. The activation of PI3K or AKT alone is sufficient to increase VEGF expression and that PI3K signaling is required for growth factor-induced VEGF expression in endothelial cells ${ }^{15}$. VEGF expression is also induced by growth factors and oncogenes such as Ras through the activation of MAP kinases including ERK1/2, which regulate growth factor-induced cell growth and tumor growth ${ }^{16}$. VEGF transcriptional activation is mainly regulated by HIF-1 in response to hypoxia and growth factors, and HIF-1 expression is in turn regulated by the activation of ERK1/2 in response to growth factor stimulation and hypoxia ${ }^{17,18}$ Thus, PI3K, AKT, 
and ERK1/2 can cooperate to play an important role in regulating HIF-1 and VEGF expression in response to growth factors and hypoxia. However, the role of VEGF in ROS signaling is still elusive, and the relationship between the ROS and VEGF remains to be elucidated. Our goal was to investigate if PI3K, AKT, and ERK1/2 are downstream of ROS signaling in inducing VEGF expression. Although we do not understand completely the highly complex nature of the relationship between these pathways, we have obtained sufficient preliminary data to study defined components in these signaling pathways, and to elucidate the potential molecular mechanisms of PI3K, AKT, and ERK1/2 in ROS-mediated VEGF expression.

\section{VEGF and Angiogenesis}

Tumor growth and metastasis were proposed to be angiogenesis-dependent in $1971^{19}$. Angiogenesis is the process by which new blood capillaries are generated from the pre-existing vasculature. The process involves multiple steps including dissolution of the basement membrane of the vessel, endothelial cell proliferation and migration, formation of a new vessel lumen and vessel branches, as well as maturation of the new vessel by the recruitment of pericytes and the formation of basement membrane $^{20}{ }^{21}$.

Recent studies have indicated that the VEGF and VEGF receptor signaling system and the angiopoietin/Tie2 signaling system are central regulators of embryonic angiogenesis $^{22}$. VEGF and its receptors are the major regulators of the phase of vessel morphogenesis in angiogenesis, while Ang-1 and its receptor, Tie-2, are implicated in 
the vascular maturation phase $\mathrm{e}^{23}$. VEGF expression is regulated by tissue oxygen content and by growth factors and cytokines, including platelet-derived growth factor, epidermal growth factor, insulin, insulin-like growth factor-I, and tumor necrosis factor $\alpha$. VEGF transcription is regulated by many transcription factors including AP-1, NF- $\kappa \mathrm{B}$ and HIF-1 $\alpha$. Hypoxia is the major physiological stimulus for VEGF expression. Hypoxia stimulates VEGF expression through gene transcription, mRNA stabilization and translational regulation. The transcriptional regulation of VEGF is mediated by HIF-1, which regulates both hypoxia- and growth factor-induced VEGF expression in tumor cells ${ }^{24}$.

Roles of PI3K, AKT, ERK1/2, AP-1 and NF- $\kappa B$ in angiogenesis

PI3K are heterodimers comprised of a $110-\mathrm{kDa}$ catalytic subunit and an $85-\mathrm{kDa}$ regulatory subunit ${ }^{25}$. PI3K catalyzes the phosphorylation of phosphatidylinositol-containing lipids at their 3-end position. Receptor tyrosine kinases activate PI3K, and this activation has been implicated in several human cancers. Several cellular functions such as proliferation, differentiation, anti-apoptosis, tumorigenesis and angiogenesis have been linked to PI3K activity. An important downstream target of PI3K is the serine-threonine kinase AKT. PI3K catalyzes the production of PtdIns-3,4-P2 and PtdIns-3,4,5-P3 to help recruiting AKT and PDK1 to the membrane ${ }^{26272829}$. The role of PI3K in angiogenesis, an important process involved in neovascularization, has already been established ${ }^{30}$. The activated receptor tyrosine kinases increase HIF-1 $\alpha$ protein synthesis via PI3K/AKT pathway and MEK/ERK 
pathway $^{31}$. Activation of oncogene Ras and the activation of PI3K pathway stimulate the expression and secretion of VEGF in tumor cells. PI3K/AKT pathway regulates the expression of VEGF via HIF-1 $\alpha$ independently of oxygen concentration in cells $^{32,33}$

It was initially observed that $\mathrm{p} 85$, the regulatory subunit of PI3K, is constitutively associated with and phosphorylated by Flk-1/KDR, resulting in increased PI3K and AKT activities in vitro. Also, VEGF-induced endothelial cell survival was blocked by wortmannin and LY294002, pharmacological inhibitors of PI3K, and by overexpression of a dominant-negative form of AKT. The direct roles of $\mathrm{PI} 3 \mathrm{~K}$ and $\mathrm{AKT}$ in regulating angiogenesis was obtained by the forced expression of PI3K or AKT by the avian retroviral vector RCAS in the CAM, and it is found that the forced expression of active forms of PI3K or AKT by RCAS vector greatly increased the number of the sprouting vessels and size of the vessels to induce angiogenesis in vivo, suggesting that PI3K or AKT activation is sufficient for inducing angiogenesis ${ }^{34}$.

Mitogen-activated protein kinases (MAPKs) compose a family of protein kinases that are activated by extracellular stimuli to phosphorylate specific serines and threonines on protein substrates. Among these, ERK1 and ERK2 are widely expressed and are involved in cell proliferation and tumor growth induced by carcinogens. The activation of ERK1/2 was important for regulating angiogenesis induced by growth factors and integrin. AP-1 and NF- $\mathrm{BB}$ are downstream of ERK1/2 signaling. AP-1 and NF- $\mathrm{KB}$ were also implicated in regulating angiogenesis 
and inflammation. However, there is a lack of direct evidence to link ROS, PI3K, AKT, ERK1/2, AP-1, NF- $\mathrm{KB}$ and angiogenesis.

WC-Co nanoparticles and its potential regulatory mechanisms

WC-Co is widely used as cemented carbide hard metal in a wide range of products in aerospace, automobiles, and home appliances. In contrast to hard metals, conventional materials have hardness and toughness that are mutually exclusive. WC-Co nanoparticles have many advantages over fine particles including the greatly improved toughness, hardness, and wear resistance. Occupational exposure to WC-Co has been associated with an increased risk of lung diseases including lung cancer. Previous studies showed that WC-Co treatment induces micronuclei formation in rat $\operatorname{lung}^{35}$. During various processes, workers are exposed to various particle sizes of WC-Co heavy metal including nanoparticles. Recent evidence indicates that nanoparticles exhibit a higher deposition in all regions of the respiratory tract when compared to the fine particles, and that exposure to nanoparticles may induce cytotoxicity, pulmonary inflammation, and/or other adverse effects in the cells and lung $^{36}$. However, the molecular mechanisms by which WC-Co exposure causes lung injury and carcinogenesis remain to be clarified. In this study, we found that WC-Co nanoparticles increase ROS production in the cells, which induces other cellular signaling molecules such as AKT and ERK1/2 activation. AP-1 and NF- $\mathrm{KB}$ are important transcription factors involved in lung injury and inflammation, VEGF is a potent angiogenic inducer. 
We found that low doses of WC-Co nanoparticles increased the transcriptional activation of AP-1, NF- $\mathrm{KB}$, and VEGF. These results are consistent with the nanoparticle effect in increasing oxidative stress and generation of ROS. ROS are produced by all aerobic organisms through the oxygen reduction process and can be induced by growth factors and cytokines. Our results showed that nanoparticles, but not fine particles of WC-Co at $5 \mu \mathrm{g} / \mathrm{cm} 2$, stimulated ROS production. As we expected, catalase inhibited ROS production, indicating that $\mathrm{H}_{2} \mathrm{O}_{2}$ is one of the species of ROS induced by nano-size WC-Co. Growing evidence has showed that $\mathrm{H}_{2} \mathrm{O}_{2}$ may act as a second messenger to regulate various cellular functions and signaling pathways including ERK, phosphatidylinositol 3-kinase (PI3K), small GTPases, NF- $\kappa B$, and nitrogen oxide(NO) pathways ${ }^{37}$, Recent reports show that PI3K and ERK may regulate ROS production ${ }^{38,39}$. We found that the inhibitors of PI3K and ERK1/2, LY294002 and U0126, did not affect ROS generation. In contrast, treatment with catalase inhibited both AKT and ERK1/2 activation. These results suggest that ROS act as upstream inducers of AKT and ERK activity in the cells. This is consistent with previous studies in a different cell system that showed $\mathrm{H}_{2} \mathrm{O}_{2}$ being upstream of AKT and ERK. We further show that WC-Co nanoparticles strongly induce AP-1, NF- $\kappa \mathrm{B}$, and VEGF transcriptional activation. Angiogenesis is critical in the injury repair, inflammation, tumor development, and neovascularization ${ }^{40}$. We further show that treatment of BEAS-2B cells with nano-sized WC-Co at low doses induced angiogenesis, while equal doses of fine-sized WC-Co did not have a strong effect on angiogenesis (data not shown). Similar results were obtained using A549 cells, 
indicating the general ability of nanoparticles to induce angiogenesis. These results are consistent with the induction of transcriptional activation of AP-1, NF- $\kappa$ B, and VEGF in this study.

Our studies elucidated cellular effects of WC-Co nanoparticles and potential molecular mechanisms involved in response to WC-Co nanoparticle exposure. However, in vivo systems are extremely complicated, the inhaled nanoparticles could react with biological components, and lead to unique biodistribution, clearance, immune response, and metabolism. It is difficult to predict the movements and location of nanoparticles after in vivo exposure in a complex system of an organism. Consequently, more studies in in vivo systems are required. We demonstrate that WC-Co nanoparticles increase ROS formation, and that activated PI3K/AKT and MEK/ERK pathways act as the downstream mediators of ROS. We also show that WC-Co nanoparticles promote AP-1, NF- $\mathrm{BB}$, and VEGF transcriptional activation. It is temping to propose the following signaling cascade: WC-Co nanoparticles induce ROS generation leading to AKT and ERK activation, which in turn activates AP-1, NF- $\kappa \mathrm{B}$ and VEGF transcription. Thus, an important future direction is to test whether transcriptional activation of AP-1, NF- $\mathrm{KB}$, and VEGF is mediated through ROS production, AKT and ERK. 


\section{Conclusion}

In conclusion, our studies provide a fundamental understanding of the effects of WC-Co nanoparticles in the lung epithelial cells and in CAM angiogenesis model. We have identified crucial roles of ROS and other signaling molecules (PI3K/AKT, MEK/ERK, AP-1, NF-אB, and VEGF) in regulating angiogenesis induced by WC-Co nanoparticles. Occupational Safety and Health Administration (OSHA) has specifically noted the need for mechanistic information in order to assess the risk of the nanoparticles. After we learn about the essential biological responses and the underlying mechanisms of nanoparticle toxicity, we can begin to develop mechanism-based interventions, such as specific antioxidant therapies and novel chemical approaches to decrease the proangiogenic toxicity of WC-Co nanoparticles and other nanoparticles. 


\section{Reference List}

1. Nanoscience and nanotechnolog ies: opportunities and uncertainties. The Royal Society, Royal Academy of Engineering, 2004.

2. Amy K. Madl, Kent E. Pinkerton. Health effects of inhaled engineered and incidental nanoparticles. Critical Reviews in Toxicology, 8 : 629-658,2009.

3. Brook T Mossman, Paul J Borm, Vincent Castranova, Daniel L Costa, Kenneth Donaldson, Steven Kleeberger. Mechanisms of action of inhaled fibers, particles and nanoparticles in lung and cardiovascular diseases. Particle and Fiber Toxicology, 4:4,2007.

4. Yin H, Casey PS, McCall MJ, Fenech M. Effects of Surface Chemistry on Cytotoxicity, Genotoxicity, and the Generation of Reactive Oxygen Species Induced by ZnO Nanoparticles. Langmuir, 2010.

5. Eun-Jung Parka, Jongheop Yib, Kyu-Hyuck Chungc, Doug-Young Ryud, Jinhee Choie and Kwangsik Parka. Oxidative stress and apoptosis induced by titanium dioxide nanoparticles in cultured BEAS-2B cells. Toxicology letters, 3: 222-229, 2008.

6. Puzanowska-Tarasiewicz H, Kuźmicka L, Tarasiewicz M. Pol Merkur Lekarski.Reactive nitrogen and oxygen species.160:338-340, 2009. 
7. Poyton RO, Ball KA, Castello PR.Mitochondrial generation of free radicals and hypoxic signaling.Trends Endocrinol Metab. 7:332-340. 2009.

8. Kulbacka J, Saczko J, Chwiłkowska A.Pol Merkur Lekarski. Oxidative stress in cells damage processes. 27:44-47. 2009.

9. Messmer-Blust A, An X, Li J, Hypoxia-regulated angiogenic inhibitors.Trends Cardiovasc Med., 19:252-256.2009.

10. Arvelo F, Cotte C., Hypoxia in cancer malignity.Invest Clin., 50:529-546,2009.

11. Pouyssegur J, Dayan F, Mazure N. Hypoxia signalling and angiogenesis. Approaches to enforce tumour regression. Nature Insights, 2006.

12. Dayan F, Roux D, Brahimi-Horn MC, Pouyssegur J, Mazure NM. The oxygen-sensor factor inhibiting HIF-1 (FIH) controls the expression of distinct genes through the bi-functional transcriptional character of HIF-1 $\alpha$. Cancer Res., 2006.

13. Mazure NM, Brahimi-Horn MC, Berta MA, Benizri E, Bilton RL, Dayan F. HIF-1 : master and commander of the hypoxic world. A pharmacological approach to its regulation by siRNAs. Biochem Pharmacol, 68: 971-80, 2004. 
14. Mazure NM, Brahimi-Horn MC, Berta MA, Benizri E, Bilton RL, Dayan F. HIF-1 : master and commander of the hypoxic world. A pharmacological approach to its regulation by siRNAs. Biochem Pharmacol, 68: 971-80, 2004.

15. Jiang BH, Liu LZ. PI3K/PTEN signaling in angiogenesis and tumorigenesis. Adv Cancer Res., 102:19-65. 2009.

16. Hong Zheng, Christine Wasylyk,Abdelkader Ayadi, Joseph Abecassis, Jack A Schalken, Hermann Rogatsch,Nicolas Wernert, Sauveur-Michel Maira, Marie-Christine Multon and Bohdan Wasylyk. The transcription factor Net regulates the angiogenic switch, Genes Dev., 17: 2283-2297, 2003.

17. Dewhirst MW, Cao Y, Moeller B. Cycling hypoxia and free radicals regulate angiogenesis and radiotherapy response.Nat Rev Cancer. 8:425-437,2008.

18. Michiels C, Minet E, Michel G, Mottet D, Piret JP, Raes M. HIF-1 and AP-1 cooperate to increase gene expression in hypoxia: role of MAP kinases. IUBMB Life., 52:49-53,2001.

19. FOLKMAN, J. Tumor angiogenesis: Therapeutic implications.

N. Engl. J. Med. $285: 182-1186,1971$. 
20. Risau,W. Mechanisms of angiogenesis. Nature, 671-674,1997.

21. Peter Carmeliet \& Rakesh K. Jain,Angiogenesis in cancer and other diseases. Nature 407: 249-257,2000.

22. Folkman,J. Tumor angiogenesis. Adv. Cancer Res. 19:331-358.1974.

23. Folkman,J. Angiogenesis in cancer, vascular, rheumatoid and other disease. Nat. Med. 1:27-31.1995.

24. Caroline Treins, Sophie Giorgetti-Peraldi, Joseph Murdaca and Emmanuel Van Obberghen. Regulation of Vascular Endothelial Growth Factor Expression by Advanced Glycation End Products, Journal of Biological Chemistry, 276:43836-43841.2003.

25. Carpenter CL, Duckworth BC, Auger KR, Cohen B, Schaffhausen BS, Cantley L C. Purification and characterization of phosphoinositide 3-kinase from rat liver. J Biol Chem 265: 19704-19711,1990.

26. Vanhaesebroeck, B. and Waterfield, M. D. Signaling by distinct classes of phosphoinositide 3-kinases. Exp.Cell Res., 253: 239-254, 1999. 
27. Chen, H. C. and Guan, J. L. Association of focal adhesion kinase with its potential substrate phosphatidylinositol 3-kinase. Proc.Natl.Acad.Sci.U.S.A, 91: 10148-10152, 1994.

28. Vivanco, I. and Sawyers, C. L. The phosphatidylinositol 3-Kinase AKT pathway in human cancer. Nat.Rev.Cancer, 2: 489-501, 2002.

29. Roymans, D. and Slegers, H. Phosphatidylinositol 3-kinases in tumor progression. Eur.J.Biochem., 268: 487-498, 2001.

30. Jiang, B. H., Zheng, J. Z., Aoki, M., and Vogt, P. K. Phosphatidylinositol 3-kinase signaling mediates angiogenesis and expression of vascular endothelial growth factor in endothelial cells. Proc.Natl.Acad.Sci.U.S.A, 97: 1749-1753, 2000.

31. Narjes Babchia, Armelle Calipel, Frédéric Mouriaux, Anne-Marie Faussat and Frédéric Mascarelli. The PI3K/Akt and mTOR/P70S6K Signaling Pathways in Human Uveal Melanoma Cells: Interaction with B-Raf/ERK. Investigative Ophthalmology and Visual Science. 51:421-429.2010.

32. Min Zeng, Hirotoshi Kikuchi, Maria S. Pino, Daniel C. Chung, Hypoxia Activates the K-Ras Proto-Oncogene to Stimulate Angiogenesis and 
Inhibit Apoptosis in Colon Cancer Cells. PLoS ONE 5:12-17,2007.

33. Bing-Hua Jiang and Ling-Zhi Liu. PI3K/PTEN Signaling in Angiogenesis and Tumorigenesis. Adv Cancer Res. ,102: 19-65. 2009.

34. Yong Qian, Linda Corum, Qiao Meng, John Blenis, Jenny Z. Zheng, Xianglin Shi, Daniel C. Flynn, and Bing-Hua Jiang. PI3K induced actin filament remodeling through Akt and p70S6K1: implication of essential role in cell migration. Am J Physiol Cell Physiol 286: 153-163, 2004.

35. De Boeck M, Hoet P, Lombaert N, Nemery B, Kirsch-Volders M, Lison D. In vivo genotoxicity of hard metal dust: induction of micronuclei in rat type II epithelial lung cells. Carcinogenesis 24: 1793-1800,2003.

36. Gradon L, Orlicki D, Podgorski A. Deposition and retention of ultrafine aerosol particles in the human respiratory system. Normal and pathological cases. Int. J. Occup. Saf Ergon. 6: 189-207.2000.

37. Finkel T. Oxygen radicals and signaling. Curr. Opin. Cell Biol. 10: 248-253.1998.

38. Schreck R, Albermann K, Baeuerle PA.. Nuclear factor kappa B: an oxidative stress-responsive transcription factor of eukaryotic cells (a review). Free Radic. 
Res. Commun. 17: 221-237.1992.

39. Zhuang S, Kinsey G, Yan Y, Han J, Schnellmann R. ERK activation mediates mitochondrial dysfunction and necrosis induced by hydrogen peroxide in renal proximal tubular cells. J. Pharmacol. Exp. Ther.2008.

40. Ellen C. Keeley; Borna Mehrad; Robert M. Strieter, Chemokines as Mediators of Neovascularization, Arteriosclerosis, Thrombosis, and Vascular Biology. 28:1928-1936, 2008. 


\section{YINGXUE ZHU}

\section{General Information:}

Contact: 304-906-6602

E-mail: $\quad$ yxzhu1@gmail.com

Mail Address: 1020 Locust Street, Jefferson Alumni Hall, Suite 334,Philadelphia, PA, 19107

\section{Objectives:}

Research assistant, Lab Technician

\section{Profile:}

- Able to conduct a project independently including design of experiments, data analysis, troubleshooting, literature search and publication of data.

- Professional knowledge of the theories, principles, and methods in various biological field and skill in performing a wide variety of complex procedures and techniques

- Readiness to learn and use new concepts, techniques, software as the need arises

- Self motivated starter with strong organizational and time management

- Effective human relations and teamwork skills, able to accomplish work and multitask under time constraints

\section{Education:}

- West Virginia University, Morgantown, WV

M.S., Genetics and developmental biology, Dec. 2010

GPA (4.0 scale): 3.25 overall

Thesis: "mechanism of Tungsten carbide-cobalt nanoparticles induced angiogenesis"

- Shantou University College of Science

B.S., Biotechnology, June 2008

GPA (4.0 scale): 3.3 overall; 3.9 in major

\section{Academic Achievements \& Awards:}

- 2006 to $2007 \quad 3^{\text {rd }}$ Academic Scholarship of Shantou University

- 2005 to $2006 \quad 2^{\text {nd }}$ Academic Scholarship of Shantou University

- 2004 to $2005 \quad 1^{\text {st }}$ Fellowship of Shantou University

\section{Working experience:}

- July 2008 to Aug 2009 Inspection \& Quarantine Technology Center, Xiamen, China 
Department: Transgenic Gene Lab and Animal Inspection \& Quarantine Lab

Position: Technician

Responsibilities: In charge of appraising transgenic plants/products and quarantining imported/exported animal or animal products including contagion diseases and vermin at a molecular level, which include some techniques like cell culture, bacterial culture, RT-PCR, fluorescent quantitative RT-PCR, ELISA, nertralization test, gel diffusion test, haemagglutination and haemagglutination inhibition tests, complement fixation reaction

\section{Research Experience:}

- Jan. to Jun. 2008

Institute for Biomedical Research of Xiamen University, Xiamen, China

Position: Research Assistant

Made graduation-essay-based research with title of "An Attempt to Study the Effect of Anti-cancer Herbal Compounds on Nuclear Receptor TR3/Nur77" that integrated many biomedical techniques like cell culture, MTT, DNA\&RNA extraction, RT-PCR, protein purification, western blotting, etc. and succeeded in finding out dozens of anti-cancer herbal compounds, settled an innovative footstone for further research on controlling mechanism of orphan nuclear receptor TR3/Nur77 and development of TR3-targeted new anti-cancer medicines.

- Aug.2009 to June. 2010 West Virginia University, Morgantown, WV

Department: Mary Babb Randolph Cancer Center

Position: Research Assistant

Project: the mechanism of heavy mental (Arsenic and Cadmium) induced carcinogenesis, tumor transformation and angiogenesis

- June 2010 to present Thomas Jefferson University, Philadelphia, PA

Department: Pathology, Anatomy and Cell Biology

Position: Research Assistant

Projects: $\quad$ oxidative stress regulated microRNA in ovarian cancer

Skilled in experiments commonly used in cell signaling and molecular biology researches, including cell culture; Western Blot; ELISA; micro-array; RT-PCR; angiogenesis experiments including tube formation assay, cell proliferation assay, cell invasion and migration assay; SeaPlaque Agarose for colonies; NADPH oxidase activity Assay; siRNA and pre-miRNA transfection; adenovirus amplification, titer and transformation; retrovirus production and transformation; productin, titration and transformation of lentivirus; infection; subcloning(classic subcloning, transforming bacterial, screening for recombinants); stable cell line construction; reporter construction; reporter assay; CAM assay, etc.

Also in charge of routine maintenance and orders of laboratory supplies and 
equipment including chemicals, biological materials, carbon dioxide can, liquid nitrogen, etc

\section{Manuscript:}

- Tungsten Carbide-cobalt Nanoparticles induce Reactive Oxygen Species, AKT, ERK, AP-1, NF-kB, VEGF, and Angiogenesis

- Cadmium induces tumor Angiogenesis through PI3K/Akt/p70S6K1 and ERK1/2 signaling pathways in human airway epithelial cells

\section{Reference:}

Bing-Hua Jiang, Ph.D.

Professor, Department of Pathology, Anatomy and Cell Biology

Thomas Jefferson University

1020 Locust Street, Room 334

Philadelphia, PA 19107

Phone: 215-503-6147, email: bhjiang@jefferson.edu

Bingyun Li, Ph.D.

Assistant Professor, Department of Orthopaedics

West Virginia University

Morgantown, WV 26506

Phone: 304-293-7042 email: bli@hsc.wvu.edu

Lingzhi Liu, M.D., Ph.D.

Assistant Professor, Department of Pathology, Anatomy and Cell Biology

Thomas Jefferson University

1020 Locust Street, Room 334

Philadelphia, PA 19107

Phone: 215-503-6146, email: Ling-Zhi.Liu@jefferson.edu 